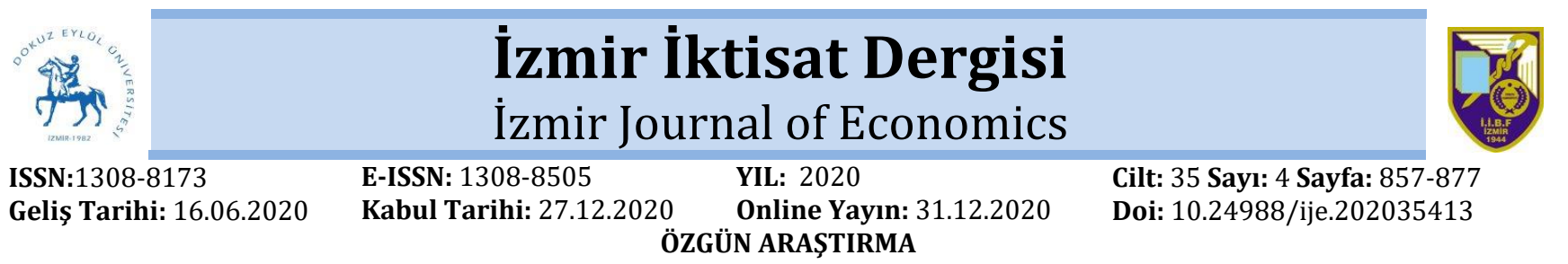

\title{
Küresel Finans Krizinin Finansal Bulaşıcılık Modeli ile BİST30 Endeksinde Analizi
}

\author{
Didem ÖZDEN ${ }^{1}$, Mert URAL ${ }^{2}$
}

Özet

Küresel finans krizi birçok ülkenin finans piyasalarını ve makroekonomik değişkenlerini önemli ölçüde etkilemiştir. Bu durum ülkenin sadece temel göstergelerindeki yapısal sorunlara değinilerek açıklanamamıştır. Bu nedenle bulaşıcılık, son dönemde finansal bozuklukların yayılma etkisini analiz etmek adına sıkça kullanılmaya başlanmıştır. Bu çalışmanın amacı, 5 Temmuz 2006 - 12 Kasım 2019 dönemi günlük kapanış fiyatları üzerinden yatay kesit mutlak sapmaya dayalı olarak S\&P500 endeksi ile BİST30 endeksi arasında finansal bulaşıcllık etkisi ve sürü davranışının varlığının test edilmesidir. 2008 küresel finans krizinin etkilerini inceleyebilmek üzere analiz dönemi ayrıca kriz içeren ve kriz sonrası olmak üzere iki alt döneme ayrılmıştır. Geliştirilen "Finansal Bulaşıcılık Modeli" her ülkenin borsa endeksi kapanış fiyatları farklı para birimleri cinsinden hesaplanarak hem EKKY hem de asimetrik GARCH tipi modeller yardımıyla analiz edilmiştir. Sonuç olarak, tüm dönem, kriz içeren dönem ve kriz sonrası dönem için finansal bulaşıcılık etkisinin daima var olduğu buna karşın, krizin sürü davranışı ile yayılma etkisi beklentinin aksine sadece kriz sonrası dönemde istatistiki ve iktisadi olarak anlamlı bulunmuştur. Çalışmanın önemli bir bulgusu, her analiz dönemi için para cinsi farklılaştı̆̆ında finansal bulaşıcılık katsayısı ve krizin yayılma etkisini gösteren sürü davranışı katsayısı işaretlerinin değişmediği ve bu yüzden değişkenler için para cinsi uyumlaştırmasına gerek olmadığı yönündedir.

Anahtar Kelimeler: Finansal Bulaşıcılık, Yatay Kesit Mutlak Sapma, Asimetrik GARCH, Half-Life Oynaklık JEL Kodu: C22, C58, G15

\section{Analysis of Global Financial Crises In BIST30 Index By Using Financial Contagion Model}

\begin{abstract}
The global financial crisis has significantly affected the financial markets and macroeconomic variables of many countries. This could not be explained by addressing only structural problems in the basic indicators of the country. For this reason, contagion has been used frequently to analyze the spread of financial disorders recently. The aim of this study is to test the presence of financial contagion effect and herding behavior between S\&P500 index and BIST30 index based on the cross-sectional absolute deviation by using the daily closing prices for the period of January 5, 2006 - November 12,2019 . In order to examine the effects of the 2008 global financial crisis, the analysis period is also divided into two sub-periods, including crisis and post-crisis. The developed "Financial Contagion Model" analyze with the help of both OLS and asymmetric GARCH type models in different currencies. As a result, financial contagion effect has always existed for the whole period, the period including the crisis and the post-crisis period; however, the spreading effect of the crisis through herd behavior was found to be statistically and economically significant only in the post-crisis period, contrary to expectations. An important finding of the study is that the financial contagion coefficient and the signs of the herd behavior coefficient do not change when the currency type differs for each analysis period, so there is no need for currency harmonization for variables.
\end{abstract}

Keywords: Financial Contagion, Cross-Sectional Absolute Deviation, Asymmetric GARCH, Half-Life Volatility JEL Code: C22, C58, G15

\section{GİRİ}

Küresel finans krizi birçok ülkenin finans piyasalarını ve makro ekonomik değişkenlerini önemli ölçüde etkilemiştir. Bu durum ülkenin sadece temel göstergelerindeki yapısal sorunlar üzerinden açıklanamamıştır. Bu nedenle bulaşıcılık kavramı, son dönemde finansal sorunların yayılma etkisini analiz etmek adına sıkça kullanılmaya başlanmıştır. 1990’lı yıllarda özellikle yükselen piyasa

ATIF ÖNERÍSí (APA): Özden, D., Ural, M. (2020). Küresel Finans Krizinin Finansal Bulaşıcılık Modeli ile BİST30 Endeksinde Analizi. İzmir Journal of Economics, 35(4), 857-877. Doi: 10.24988/ije.202035413

1 Dokuz Eylül Üniversitesi, Sosyal Bilimler Enstitüsü, İktisat Anabilim Dalı, Buca/IZZMíR, E-MAIL: didem_ozden@hotmail.com, ORCID: 0000-0003-2072-9168

2 Prof. Dr., Dokuz Eylül Üniversitesi, İktisadi ve İdari Bilimler Fakültesi, İktisat Bölümü, Buca/İZMİR, E-MAIL: mert.ural@deu.edu.tr, ORCID: 0000-0003-3252-846X 
ekonomilerinde yaşanan finansal krizlerin (1994 Meksika Krizi, 1997 Asya krizi, 1998 Rusya Krizi) en önemli özelliği, bir ekonomideki sorunların hızla diğer ekonomilere de yayılmasıdır.

Krizin ortaya çıktığı andan itibaren ülkeler arasındaki aktarım bulaşıcılık kavramı ile açıklanırken, yatırımcıların piyasaya verdiği tepkiler sürü davranışı ile açıklanmaktadır. Bunun ötesinde, sürü davranışı finansal piyasalardaki bulaşıcılığın uzun dönemde yatırımcı kararları üzerindeki etkisini analiz etmektedir. Bulaşıcılığa neden olan doğrudan etkiler piyasalar arası aktarım mekanizmalarında meydana gelen değișimler olurken, dolaylı etkiler ise yatırımcı davranışlarında oluşan değişimlerdir. Ancak kullanılan değişkenler krizin ortaya çıktığı anı göstermek yerine krizin uzun dönemdeki yayılma etkisini ülkeler ve değişkenler bağlamında göstermektedir.

Ülkelerin krizden etkilenme nedenleri sadece ticaret ve/veya sermaye hareketleri kaynaklı finansal bulaşıcılığa dayandırılmamalıdır. Ekonomideki baskılar bağımsız bir şekilde diğer ülkelerin gelişiminden veya ortak şoklardan da kaynaklanabilmektedir. Sürdürülemeyen para ve maliye politikaları ya da döviz kuru çıpası altında oluşan cari açıklar bir ülkeyi bulaşıcılık olmasa bile krize sürükleyebilmektedir (Caramazzo, Ricci ve Salgado, 2000:1-48).

Kaminsky, Reinhart ve Vegh (2003), yaptıkları bir çalışmada bulaşıcılığın temelde üç unsuru olduğu vurgulanmaktadır. Birincisi, bulaşan krizin patlak vermesinden önce bu ülkelere önemli bir uluslararası fon akımı olması gerektiğidir. İkincisi, bu ülkelere borç veren ortak uluslararası mali yatırımcılar bulunmalıdır. Üçüncüsü ise, sürprizöngörülmemiş açıklamalar yapılması ve yatırımciların bunlara hazırlıksız yakalanmaları gerektiğidir. Son yirmi yılda bazı ülkelerde yaşanan devalüasyonlar ve ödeme güçlükleri diğer ülkelerde dolaysız ve ani zincirleme etkilere neden olmuştur. $\mathrm{Bu}$ durum, hızlı ve şiddetli bulaşıcılık şeklinde tanımlanmaktadır. Ancak farklı koşullarda, benzer olayların ani uluslararası etkiler göstermediği de görülmüştür. Bu nedenle, her iki durumu ayırt etmek adına hızlı ve şiddetli bulaşıcılık dönemleri "korkunç üçleme" kavramı ile açıklanmaya başlanmıştır.

Teorik açıdan piyasa katılımcıları arasında sürü davranışını takip etmek, bunun yanında belirsiz inançlar ve bilgi asimetrisini araştırmak bulaşıcılığı vurgulamak açısından önemli faktörlerdir. Ampirik açıdan ise getirilerin aşırı olduğuna karar vermek krizde etkin politikalar uygulamak için bir önkoşuldur. Piyasalar ve ülkeler arasında şokların yayılmasını daha iyi analiz edebilmek için yüksek frekanslı finansal verilerin kullanılması gerektiği vurgulanmaktadır (Dungey ve Tambakis, 2003:1-23).

Kahneman ve Tversky (1979) tarafından risk altında karar alma sürecinin yatırımciların davranışları bağlamında ele alınması, davranışsal iktisadın bir başlangıcı olarak kabul edilebilir. Risk ve getiriyi birlikte ele alarak finansal iktisatta psikoloji temelli bir yaklaşım sağlanmaya çalışılmıştır. Bu yaklaşım olasılık teorisi ve sezgi - bilişsel önyargılar olmak üzere iki aşamadan oluşmaktadır. Olasılık teorisi, bireylerin risk ile karşı karşıya kaldıklarında nasıl karar verdiklerini analiz etmektedir. Bu şekilde, portföy seçimindeki davranışsal yaklaşımların açıklanmasında psikolojik bir temel sağlanmış olmaktadır. Sezgi ve bilişsel önyargllar ise bireylerin riski nasıl değerlendirdiği hakkında bilgi vermektedir. Burada varlıkların fiyatlanmasında bireylerin davranışları psikolojiye dayandırılarak açıklanmaktadır. Olasılık teorisinde, portföy seçimi bir karar verme sürecini içermektedir (Shefrin ve Statman, 2003:54).

Hisse senedi piyasalarında herhangi bir nedenden dolayı getirilerde oluşan artışların, gelecekte de devam edip etmeyeceğinin bilinmemesi belirsizlik yaratmaktadır. Belirsizlik ise piyasalarda riske neden olmaktadır. Gerçekleşen değer ile beklenen değer arasındaki sapma ne kadar fazla olursa risk de o kadar artmaktadır (Fama, 1998:283306). Yatırımcıların davranışlarında 
yakınsama mı yoksa ıraksama mı olduğu sürü davranışı bağlamında ele alınmaktadır. Yatırımcilar aynı zamanda karar veren bir grubu temsil etmektedir. Karar alma sürecinde ise en önemli olgu beklentiler olmaktadır (Kahneman ve Tversky, 1979:263).

Elkhaldi ve Abelfatteh (2014) tarafından sürü davranışı, "küresel piyasa performansının yatırımcılar tarafından taklit edilmesi" şeklinde tanımlanmaktadır. Bununla beraber, yanlı tercihlere ve inançlara dayanan irrasyonel düşünceleri içermesi nedeni ile kötü varlık değerleme süreci olarak da değerlendirilebilmektedir.

Sürü davranışı Harry Markowitz'in ortalama varyans modeline kadar dayandırılabilir. Markowitz'e göre fayda; varlı durumlarına değil, varlık değişikliklerine bağlıdır. $\mathrm{Bu}$ bağlamda, problemlerin kıyaslanması seçeneklerin değerlendirildiği referans noktasıdır. Referans noktası kazanç ve kayıpların değerlendirilmesi için temel noktadır. Beklenti teorisi ile fayda teorisi arasındaki fark budur. Yatırımcıların piyasadaki diğer yatırımcıları taklit etmesi bir anlamda beklentilerin yönetilmesidir. Sürü davranışı ilk önce fayda teorisi bağlamında açıklanmaya çalışılmıştır. Ancak referans noktasının önemi anlaşıldığında beklenti teorisi geliştirilmiştir (Kahneman, 2015:321333).

Hisse senedi piyasaları için yapılan analizlerde yatırımcı davranışlarının değerlendirilmemesi yetersiz sonuçların elde edilmesine ve yanlış yorumlara neden olacaktır. Nitekim, kriz sonrasında piyasada oluşan yatırımcı davranışlarının incelenmesi krizin yayılmasında sürü davranışının ne kadar etkili olduğunu göstermesi açısından önemlidir.

Bu çalışmanın amacı, 5 Ocak 2006 - 12 Kasım 2019 dönemi günlük kapanış fiyatları üzerinden yatay kesit mutlak sapmaya dayalı olarak S\&P500 endeksi ile BİST30 endeksi arasında finansal bulaşıcılık etkisi ve krizin sürü davranışı ile yayılma etkisinin varlığını test etmektir. $\mathrm{Bu}$ bağlamda ikinci bölümde literatür incelemesine yer verilmiş, üçüncü bölümde finansal bulaşıcılık modeli, asimetrik
GARCH tipi modeller ve half-life oynaklik metodolojisi anlatılmış, dördüncü bölümde veri seti ve analiz bulgularına yer verilmiş, beşinci bölümde ise genel değerlendirme yapılmıștır. Bu çalışmanın literatüre katkısı, krizin bulaşıcllık etkisinin sürü davranışı ile beraber araştırılmasıdır. Bir diğer katkısının ise, üzerinde sıkça tartışılan analize konu değişkenlerin aynı para birimi cinsinden olması gerekliliği ve sonuçlar üzerindeki etkisinin incelenmiş olmasıdır.

\section{LITTERATÜR TARAMASI}

Bekaert ve Ehrmann (2011) tarafindan küresel krizin sektörel bazda etkilerini analiz etmek amaciyla 7 Ağustos 2007 ile 15 Mart 2009 dönemi ele alınmış, üç faktörlü finansal varlıkları fiyatlama modeli kullanılmıștır. Küresel ve yerel faktörler çerçevesinde varlık fiyatları kullanılarak krizin etkileri tahmin edilmeye çalışılmıştır. ABD piyasalarından 55 ülkeyi içeren küresel finans sektörüne sistematik bir bulaşıcllık bulunmuştur. Ancak bu sonuç istatistikî olarak anlamlı olmasına karşın iktisadi anlamda çok küçük bir etki bulunmuştur.

Hwang, In ve Kim (2011) tarafından 15 gelişmiş, 23 gelişmekte olan toplam 38 ülkeye ait veriler DCC-GARCH Modeli ile analiz edilmiştir. 1 Ocak 2005 - 31 Ağustos 2009 dönemi Küresel Finans Krizi'ni 1 Ocak 1996 31 Aralık 2013 dönemi ise Doğu Asya Krizini analiz etmek üzere seçilmiştir. Finansal bulaşıcllık etkisinin sadece gelişmiş ülkelerde değil, aynı zamanda gelişmekte olan ülkelerde de görüldüğü vurgulanmıștır. Küresel Finans Krizi'nin ülke hisse senetleri arasındaki korelasyonun Doğu Asya Krizi ile karşılaştırıldığında daha yüksek olduğu bulunmuştur. Ayrıca krizin erken dönemlerinde finansal bulaşıcılık etkisi daha fazla görülürken bu bulaşıcıllğın daha sonra sürü davranışına döndüğü belirtilmiştir.

Christie ve Huang (1995) tarafından ABD hisse senedi piyasasında yer alan katılımcların yatırımcı davranışlarını analiz etmek amaçlanmıştır. Piyasa ortalamasına göre bireysel varlı getirilerinin ortalamaya 


\section{D. ÖZDEN - M. URAL}

yakınlığı getirilerin Yatay Kesit Mutlak Sapma (YKMS) ölçüsü ile hesaplanmıştır. Çalışmada iki dönem farklı veri türleri ile ele alınmıştır. İlk olarak günlük veri kullanılmış ve 1962 1988 dönemi incelenmiștir. Daha sonra aylık veri kullanılmış ve 1925-1988 dönemi incelenmiştir. Ancak her iki dönemde de sürü davranışı bulunamamıştır.

Chang, Cheng ve Khorana (2000) tarafından Kuzey Kore, Tayvan, ABD, Hong- Kong ve Japonya piyasaları Ocak 1963- Aralık 1997 dönemi için incelenmiştir. YKMS'nin aksine aşırı fiyat hareketlerinin ABD ve Hong-Kong piyasalarında doğrusal bir şekilde arttığı görülmüştür. Ancak Kuzey Kore ve Tayvan için istatistiksel olarak anlaml, doğrusal olmayan bir ilişki bulunmuştur. Çalışmada Kuzey Kore ve Tayvan'da sürü davranışı tespit edilirken ABD ve Hong-Kong'da sürü davranışı tespit edilememiştir. Japonya'da ise istatistiksel olarak anlamlı da olsa çok küçük bir sürü davranışı bulgulanmıștır.

Kıraç (2015) tarafından 11 farklı ülkeye ait borsa endeksleri kişi başına düşen gelire göre sınıflandırılarak Küresel Finans Krizi'nin bulaşıcılık etkisi araştırılmıştır. Üst gelir ve alt orta gelir grubuna giren ülkelerin borsa endeksleri kullanılmıștır. Analiz kriz öncesi dönem (5 Ocak 2005-31 Temmuz 2007), kriz içeren dönem (1 Ağustos2007-31 Ağustos 2009) ve kriz sonrası dönem (1 Eylül 2009-1 Temmuz 2014) olarak üçe ayrılmıştır. Her üç dönemde DCC-GARCH Modeli ile analiz edilmiştir. Üst gelir grubunda S\&P500 endeksinde meydana gelen \%1'lik artış kriz öncesi dönemde en fazla DAX en az NIKKEI, kriz döneminde en fazla FTSE en az NIKKEI, kriz sonrası dönemde ise en fazla DAX en az KOSPİ borsalarında artış göstermiştir. Üst-orta gelir grubunda S\&P500 endeksinde meydana gelen \%1'lik artış kriz öncesi, kriz dönemi ve kriz sonrası dönemlerde en fazla BOVESPA en az SSEC borsalarında bir artışa neden olmuştur. Alt orta gelir grubu ülkelerinde S\&P500 endeksinde meydana gelen \%1'lik artış kriz öncesi, kriz dönemi ve kriz sonrası dönemlerde en fazla SENSEX en az JAKARTA borsalarında artışa neden olmuştur.
Ergün ve Doğukanlı (2015) tarafından yapılan çalışmada Christie ve Huang'ın yöntemi kullanılarak BİST Endeksinde yer alan 15 farklı sektöre ait 4 Ocak 2000 - 28 Eylül 2012 dönemi günlük ve haftalık hisse senedi fiyatları kullanarak analiz edilmiștir. Bu bağlamda, tüm hisse senetleri, sanayii, imalat, gıda, kimya, metal, taş ve toprak, tekstil, ticaret, holding ve yatırım, mali kuruluşlar, banka, yatırım ortaklıları, gayrimenkul yatırım ortaklıları sektörlerinde sürü davranışı araștırılmıștır. Burada sürü davranışının varlığı değil finansal varlık fiyatlama hipotezinin geçerliliği tespit edilmiștir. BİST'te ve farklı sektörlerde hem günlük hem de haftalık veri kullanılarak yapılan analiz sonuçlarına göre sürü davranışına rastlanmamıştır.

\section{METODOLOJİ}

Bir ülkede finansal bulaşıcılığı tek bir nedene dayandırarak açıklamak eksik bir tanım olur. Finansal bulaşıcılığı açıklamak için çok boyutlu bir bakış açısına gereksinim vardır. Herhangi bir nedenden dolayı ortaya çıkan krizin diğer bir ülkeye bulaşması eğer temel ekonomik değişkenler ile açıklanamıyorsa bu durum "saf bulaşıcılık" şeklinde ifade edilir. Bulaşıcılık sonrasında ekonomi iyi bir denge noktasından kötü bir denge noktasına geçmektedir. Bu bağlamda finansal bulaşıcılık modeli denge durumlarındaki değişimin nedenini araştırmaktadır. Denge durumundaki değişimin sonuçları önemli olduğu kadar bu değişime neden olan sürecin de analiz edilmesi gerekmektedir.

$\mathrm{Bu}$ nedenle çalışmada, hisse senedi piyasaları arasındaki bulaşıcılık ile sürü davranışı birlikte araştırılacaktır. Bu bağlamda finansal bulaşıcılığı analiz etmek için oluşturulan En küçük kareler yöntemine (EKKY) dayalı modele ülkeye özgü bir faktör olan sürü davranışı katsayısı dâhil edilmektedir. $\mathrm{Bu}$ şekilde kriz sonrasında ekonomilerin denge durumlarında oluşan değişim süreci ülkelere özgü bir faktör kullanılarak analiz edilmektedir. İki bağımsız değişken kullanarak geliştirdiğimiz "Finansal Bulaşıcılık Modeli" aşağıdaki gibi ifade edilmiştir: 
$\left(R_{d, t}-R_{f}\right)=c+\alpha_{1}\left(R_{m, t}-R_{f}\right)+\alpha_{2} Y K M S_{d, t}+u_{t}$

Burada;

\begin{tabular}{|c|c|}
\hline$R_{d, t}$ & : BIST30 getiri serisi \\
\hline$R_{m, t}$ & : S\&P500 getiri serisi \\
\hline$R_{f}$ & : Risksiz faiz oranı \\
\hline$Y K M S_{d, t}$ & : Yatay Kesit Mutlak Sapma \\
\hline$\alpha_{1}$ & $\begin{array}{l}R_{m, t} \text { 'de } \% 1 \text { oranında değişimin } R_{d, t} t \\
\text { endeksinde meydana getireceği } \\
\text { değişim (finansal bulaşıcılık } \\
\text { katsayısı) }\end{array}$ \\
\hline$\alpha_{2}$ & $\begin{array}{l}Y K M S^{\prime} \text { de } \% 1 \text { oranında değişimin } \\
R_{d, t} \text { endeksinde meydana } \\
\text { getireceği değişim(sürü davranışı } \\
\text { katsayısı) }\end{array}$ \\
\hline$u_{t}$ & Hata terimi \\
\hline
\end{tabular}

En küçük kareler yöntemine dayalı analizler hem hisse senedi fiyatlarından hem de S\&P500 ve BIST30 fiyat endeks getirilerinden risksiz faiz oranı düşülerek elde edilen aşırı getiriler üzerinden gerçekleştirilmiştir. Böylece risk karşılı̆̆ı getiri serileri üzerinden yorumlar yapılmıştır.

Sürü davranışının analizinde geliștirilen temel modellerde finansal varlık getirilerinin yayılım özellikleri kullanılmaktadır. Bunu test etmek için yatay-kesit mutlak sapma (YKMS) ölçütü kullanılmaktadır. Önemli fiyat hareketlerinin olduğu dönemde piyasa katılımcılarının yatırım karalarını piyasanın ortak davranışına $\mathrm{ml}$, yoksa kendi kararlarına mi dayandıracakları YKMS ölçütü ile belirlenmektedir. Modelde yer alan YKMS değişkeni, borsa endeksinde yer alan her bir hisse senedi fiyatının borsa endeksinden mutlak değer olarak farklarının birikimli toplamının hisse senedi sayısına bölünmesiyle hesaplanmaktadır (Chang vd., 2000:5).

$Y K M S_{t}=\sqrt{\frac{\sum_{i=1}^{N}\left|R_{i, t}-R_{m, t}\right|}{N-1}}$

Burada;

$$
\begin{array}{ll}
R_{i, t} & : \text { Hisse senedi aşırı getiri serisi } \\
R_{m, t} & : \text { BIST30 endeksi aşırı getiri serisi } \\
N & : \text { Hisse senedi sayısı }
\end{array}
$$

YKMS, hisse senedi ortalama getirilerinin piyasa ortalamasına göre nasıl değiştiğini göstermektedir. Eğer piyasa katılımcıları varlık fiyatları hakkında kendi düşüncelerini piyasanın aşırı hareketli dönemlerinde bastırır ve yatırım kararlarını sadece piyasa davranışına göre değiştirirlerse bireysel varlık getirilerinde piyasa ortalamasından önemli bir sapma yaşanmayacaktır. $\mathrm{Bu}$ bağlamda YKMS'de önemli sapmalar yaşanmayacak ve YKMS katsayısı normal bir döneme göre daha küçük bir değer alacaktır. Piyasanın stresli olduğu dönemlerde bireysel getirilerin, piyasa getirileri etrafında kümelendiği görülmüştür. Bunun sonucunda, fiyatların önemli ölçüde değişim gösterdiği dönemlerde yatırımcılar piyasa ile benzer hareket edecekleri için YKMS azalacak ve sürü davranışı oluşacaktır. Piyasanın stresli olduğu aşırı fiyat düşüşlerinde, sürü davranışının bir sonuç olduğu vurgulanmaktadır.

YKMS temelinde finansal varlık fiyatlama modelleri, hisse senedi getirilerinin sadece piyasanın artan bir fonksiyonu olmadığı aynı zamanda doğrusal bir ilişkinin de olduğu gösterilmektedir. Yoğun bir sürü davranışı olduğunda getiri sapmalarında bir azalma, ılımlı bir sürü davranışı olduğunda ise getiri sapmalarında bir artış beklenmektedir (Chang vd., 2000).

Bulaşıcılık krizin başlangıç evresini açıklarken, sürü davranışı krizin ilerleme sürecine ilişkin bilgi vermektedir. Kriz dönemlerinde piyasa etkinlikten uzaklaşmaktadır. Bunun bir nedeni de yatırımcı davranışlarıdır. Piyasada rasyonel yatırımcılar olduğu kadar irrasyonel yatırımcılar da işlem yapmaktadır. Belli dönemlerde irrasyonel yatırımcların aldığ kararlar rasyonel yatırımcılar tarafından dengelenememektedir. Piyasada oluşan anomalilerin bir nedeni de haberlere verilen aşırı tepkilerdir. Bu bağlamda sürü davranışı aşırı tepkilerin olduğu dönemlerdeki hisse senedi fiyat hareketlerini analiz etmektedir (Indars ve Savin, 2017:1-45).

Finansal zaman serilerinin yüksek oynaklığa sahip olmaları doğrusal zaman serileri ile analiz edilmesini zorlaştırdığından, doğrusal olmayan koşullu değişen varyans özelliğini dikkate alan modeller geliştirilmiştir. Koşullu 
değișen varyans modellerinin temelleri; Engle (1982) tarafindan öne sürülen Otoregresif Koşullu Değișen Varyans (Autoregressive Conditional Heteroskedasticity-ARCH) modeli ile bu modelin bir türevi olup Bollersev (1986) tarafından önerilen Genelleştirilmiş Otoregresif Koşullu Değișen Varyans (Generalized Autoregressive Conditional Heteroskedasticity-GARCH) modelleridir. Günümüzde, koşullu değişen varyans modellerinin çok sayıda türev modelleri (EGARCH, TGARCH, APGARCH, FIGARCH gibi) bulunmaktadır.

ARCH ve GARCH modellerinde hata terimlerinin gecikmeli değerlerinin kareleri alınarak hesaplama yapıldığından, pozitif (iyi haber) ve negatif (kötü haber) şokların koşullu varyans üzerindeki etkisi aynı varsayılmaktadır. Oysa, karar alıcıların negatif şoklardan pozitif şoklara kıyasla daha çok etkilendikleri bilinmektedir. $\mathrm{Bu}$ durumda negatif ve pozitif şokların koşullu varyans üzerindeki etkilerinin ayrıştırılması önem kazanmaktadır. $\mathrm{Bu}$ ayrıştırma, modele dışarıdan bir kaldıraç parametresinin (asimetri katsayısı) dahil edilmesiyle gerçekleştirilmektedir. Bu çalışmada şokların asimetrik etkilerini incelemek amaciyla EGARCH, TGARCH ve APGARCH modelleri kullanılmıștır.

Nelson (1991) tarafından geliştirilen Üssel (Exponential) GARCH (EGARCH) modeli ile hem koşullu varyans üzerindeki asimetrik etkiler hem de koşullu varyansın negatif değerler alabilme olasılığı giderilmiş, böylece model logaritmik formda kurulabilmiştir (Bolgün ve Akçay, 2005:342; Tsay, 2005:125). $\operatorname{EGARCH}(p, q)$ modeli aşağıdaki gibi ifade edilebilir:

$\ln \left(\sigma_{t}^{2}\right)=\omega_{0}+\sum_{i=1}^{p} \alpha_{i} \frac{\left|\varepsilon_{t-i}\right|+\gamma_{i} \varepsilon_{t-i}}{\sigma_{t-i}}+\sum_{j=1}^{q} \beta_{j} \sigma_{t-j}^{2}$

Denklemde; $\sigma_{t}^{2}$ koşullu varyansı, $\omega_{0}$ sabit terimi, $\varepsilon_{t-i}$ getiriyi, $\alpha_{i}$ ARCH parametresini, $\beta_{j}$ GARCH parametresini ve $\gamma_{i}$ kaldıraç (asimetri) parametresini göstermektedir. Modelde $\gamma_{i} \neq 0$ olduğunda koşullu varyans üzerinde kaldıraç (asimetri) etkisinin (leverage effect) varlığından söz edilebilir. $\mathrm{Bu}$ durumda, $\gamma_{i}>0$ ve istatistiksel olarak anlaml ise, geçmişte yaşanan pozitif bir şokun (iyi haber) negatif bir şoka (kötü haber) kıyasla oynaklığ daha fazla artırdığı; aksine, $\gamma_{i}<0$ ve istatistiksel olarak anlamlı ise, geçmişte yaşanan negatif bir şokun (kötü haber) pozitif bir şoka (iyi haber) kıyasla oynaklığı daha fazla artırdığı söylenebilir (Ural, 2010:93). Bununla birlikte genel beklenti finansal piyasalarda negatif şokların oynaklığı daha fazla artırdığ yönündedir. EGARCH modelinin durağanlığı $\beta_{j}<1$ koşuluna bağlıdır ve volatilite katsayısı aşağıdaki denklem yardımıyla elde edilmektedir:

$$
\sigma=\sqrt{\exp \left\{\omega_{0}+\left(\sum_{i=1}^{p} \alpha_{i} \sqrt{\frac{2}{\pi}}\right) /\left(1-\sum_{j=1}^{q} \beta_{j}\right)\right\}}
$$

Şokların, koşullu varyans üzerindeki kaldıraç (asimetri) etkisini açıklamak üzere kullanılan diğer oynaklık modeli, Zakoian (1994) tarafından geliştirilen Eşik (Threshold) GARCH (TGARCH) modelidir. TGARCH $(p, q)$ modeli aşağıdaki gibi ifade edilebilir (Zivot ve Wang, 2006:242):

$$
\sigma_{t}^{2}=\omega_{0}+\sum_{i=1}^{p}\left(\alpha_{i}+\gamma_{i} N_{t-i}\right) \varepsilon_{t-i}^{2}+\sum_{j=1}^{q} \beta_{j} \sigma_{t-j}^{2}
$$

Denklemde $\omega_{0}>0$ ve $\alpha_{i}, \beta_{j}, \gamma_{i} \geq 0$ olup $N_{t-i}$ negatif gecikmeli hata terimlerinin bir göstergesidir ve aşağıdaki gibi negatif şoklar ile pozitif şokları ayrıştırır (Bolgün ve Akçay, 2005:342-343; Tsay, 2005:130):

$$
\left.\begin{array}{l}
\varepsilon_{t-i}<0 \text { ise, } 1 \\
\varepsilon_{t-i} \geq 0 \text { ise, } 0
\end{array}\right\}=N_{t-i}
$$

Burada, $\varepsilon_{t-i} \geq 0$ ise $\quad N_{t-i}=0$ değerini alacağından pozitif şokun varyans üzerindeki etkisi $\alpha_{i} \varepsilon_{t-i}^{2}$ kadar iken; buna karşın $\varepsilon_{t-i}<0$ ise $N_{t-i}=1$ değerini alacağından negatif şokun varyans üzerindeki etkisi $\left(\alpha_{i}+\gamma_{i}\right) \varepsilon_{t-i}^{2}$ kadar olacaktır. $\mathrm{Bu}$ modelde de $\gamma_{i}>0$ olmak koşuluyla $\quad \alpha_{i} \varepsilon_{t-i}^{2}<\left(\alpha_{i}+\gamma_{i}\right) \varepsilon_{t-i}^{2} \quad$ durumu gerçekleşeceğinden finansal piyasalarda negatif şokların oynaklığı daha fazla artırdığı 
anlașılmaktadır. TGARCH modelinin durağanlığı, $\quad\left(\alpha_{i}+\frac{\gamma_{i}}{2}+\beta_{j}\right)<1 \quad$ koşuluna bağlıdır ve volatilite katsayısı aşă̆ıdaki denklem yardımıyla elde edilmektedir (Ural, 2010:107):

$$
\sigma=\sqrt{\frac{\omega_{0}}{1-\sum_{i=1}^{p} \alpha_{i}-\frac{\gamma_{i}}{2}-\sum_{j=1}^{q} \beta_{j}}}
$$

Ding, Granger ve Engle (1993), geleneksel ARCH modellerinde yüksek frekansa sahip zaman serilerinin mutlak değeri veya karesini almak yerine, verilerin dönüşümünün verilerin kaçıncı kuvveti ile olduğunu analiz etmişlerdir. İleri sürdükleri $\operatorname{APGARCH}(p, q)$ modeli için koşullu değişen varyans denklemi aşağıdaki şekilde ifade edilebilir (Ural, 2010:95-107):

$\sigma_{t}^{\delta}=\omega_{0}+\sum_{i=1}^{p} \alpha_{i}\left(\left|\varepsilon_{t-i}\right|-\gamma_{i} \varepsilon_{t-i}\right)^{\delta}+\sum_{j=1}^{q} \beta_{j} \sigma_{t-j}^{\delta}$

Denklemde $\alpha_{i}$ ve $\beta_{i}$ standart GARCH, $\gamma_{i}$ asimetri etkisi ve $\delta$ kuvvet parametreleridir. Kaldıraç etkisi -1 ile +1 arasında $\left(-1<\gamma_{i}<1\right)$, kuvvet parametresi $0^{\prime}$ dan büyük $(\delta>0)$ değerler almaktadır. $\gamma_{i}$ negatif (pozitif) değer aldığında, geçmişte yaşanan pozitif (negatif) şokların, serinin bugünkü koşullu varyansı üzerinde geçmişte yaşanan aynı büyüklükteki negatif (pozitif) şoklara kıyasla daha derin bir etkiye neden olduğu anlamına gelmektedir. APGARCH modelinde kuvvet parametresinin 2'ye yakın çıkması koşullu standart sapma yerine koşullu varyansın modellenmesi gerektiği şeklinde yorumlanmaktadır. APGARCH modelinin durağanlığı ise, $\alpha_{i} E\left(|z|-\gamma_{i} z\right)^{\delta}+\beta_{j}<1$ koşuluna bağlıdır ve volatilite katsayısı aşağıdaki denklem yardımıyla hesaplanmaktadır:

$$
\sigma=\sqrt[\delta]{\frac{\omega_{0}}{1-\alpha_{i} E\left(|z|-\gamma_{i} z\right)^{\delta}-\beta_{j}}}
$$

Ortalamaya geri dönüş, mevcut bilgilerin oynaklığın uzun dönemli tahmini üzerinde hiçbir etkisi olmadığını ifade etmektedir. Durağan GARCH-tipi modellerde ARCH ve
GARCH parametreleri toplamının 1'e yakın olması durumunda oynaklık değeri uzun dönem ortalama düzeyine döner. Oynaklığın uzun dönem ortalama düzeyine dönme süresi, half-life (yarılanma-ömrü) şok değeri ile ölçülür (Engle ve Patton, 2001). Örneğin EGARCH modeli için oynaklık sürekliliği parametresi $\hat{P}=\sum_{j=1}^{q} \beta_{j}$ ve modelin durağanlığı $\beta_{j}<1$ koşuluna bağlıdır. TGARCH modeli için oynaklık sürekliliği $\hat{P}=\left(\alpha_{i}+\frac{\gamma_{i}}{2}+\beta_{j}\right) \quad$ ve modelin durağanlığı $\quad\left(\alpha_{i}+\frac{\gamma_{i}}{2}+\beta_{j}\right)<1$ koşuluna bağlıdır. Her iki model için de eğer $\widehat{P}<1$ ise, getiri serilerinin ortalamaya dönme eğiliminde olduğu söylenir. Buradan hareketle, half-life şok değeri aşağıdaki denklem yardımıyla hesaplanabilir (Gbenro and Moussa, 2019: 4):

$$
H L=\frac{-\ln (2)}{\ln (\widehat{\mathrm{P}})}
$$

\section{VERİ VE AMPIRIK BULGULAR}

\subsection{Veri}

Finansal Bulaşıcılık Modelinin test edilmesi amacıyla bağımlı değișken olarak BİST30 endeksi, bağımsız değişkenler olarak finansal bulaşıcilığ temsilen S\&P500 endeksi ve krizin sürü davranışı ile yayılmasını temsilen YKMS değișkenleri seçilmiştir. YKMS değişkeni, analiz dönemi boyunca BÍST30 endeksinde sürekli yer alan 22 adet hisse senedi (AKBNK, ARCLK, ASELS, BIMAS, DOHOL, EREGL, FROTO, GARAN, ISCBNK, KCHOL, KOZAA, KRDMR, PETKM, SAHOL, SISE, SODA, THYAO, TOASO, TSKB, TUPRS, VAKBNK, YKBNK) ile hesaplanmıștır. Analiz dönemi boyunca BIST30 endeksi içinde sürekli yer alan 22 hisse senedi sadece yatay kesit mutlak sapma (YKMS) serisini elde etmek için kullanılmıştır. Çalışmada 5 Temmuz 2006 - 12 Kasım 2019 dönemi (3358 gözlem) için BIST30 endeksi, S\&P500 endeksi ve BIST30 endeksi içinde sürekli yer alan 22 hisse senedinin günlük kapanış fiyatları alınmıştır. Günlük kapanış 
fiyatları üzerinden logaritmik birinci dereceden farklar $r_{t}=\ln \left(p_{t} / p_{t-1}\right)$ alınarak getiri serileri elde edilmiştir. Bununla birlikte analizler aşırı getiriler üzerinden gerçekleștirildiğinden hem S\&P500 endeksi hem de BIST30 endeksi ve hisse senetleri için 5'er yıllık tahvil faiz oranları risksiz faiz oranı olarak dikkate alınmıştır.

2008 Küresel Finans Krizinin bulaşıcılık etkisini öngörebilmek için 5 Temmuz 2006 12 Kasım 2019 analiz dönemi ayrıca iki alt döneme ayrılarak analiz edilmiştir. Bu iki alt dönemin belirlenmesinde, Ben S. Bernanke tarafından 22 Mayıs 2013 tarihinde açıklanan rapor dikkate alınmıștır. Bu kapsamda 5 Temmuz 2006 - 22 Mayıs 2013 arası (1734 gözlem) ‘Kriz İçeren Dönem' ve 23 Mayıs 2013 - 12 Kasım 2019 arası (1624 gözlem) 'Kriz Sonrası Dönem' şeklinde belirlenmiştir.

\begin{tabular}{cc}
\hline DÖNEM & TARİH ARALIĞI \\
\hline Tüm & $05 / 07 / 2006-12 / 11 / 2019$ \\
Kriz İçeren & $05 / 07 / 2006-22 / 05 / 2013$ \\
Kriz Sonrası & $23 / 05 / 2013-12 / 11 / 2019$ \\
\hline
\end{tabular}

Alana ilişkin çalışmalarda bazen yerel para birimleri bazen ortak para birimleri kullanıldığı görülmektedir. Ülkeler tarafından uygulanan para politikalarının döviz kurlarını etkileyebilmesi nedeniyle endekslerin ortak para birimine dönüştürülmesinin sakıncalı olduğu belirtilmektedir (Kasa, 1992:95; Alexander, 2001:347: Tan, 2012:77; Kocabıyık ve Kalaycl, 2014:41-42).

$\mathrm{Bu}$ çalışmada, para birimlerinin katsayılar üzerindeki etkisini görebilmek açısından borsa endeksleri hem yerel para birimleri kullanılarak hem de ortak para birimine (USD ve TL) dönüştürülerek analizler yapılmıştır. Borsa İstanbul yönergelerinden hareketle, USD'ye dönüştürmede TCMB USD alış kuru dikkate alınmıştır.

$\mathrm{Bu}$ durumda, yerel para birimleri bazlı, USD bazlı ve TL bazlı olmak üzere üç farklı para yapısı ile üç farklı dönem için öncelikle tanımlayıcı istatistikler ardından durağanlık testleri hesaplanarak yorumlanmiștır. Yer kısıtı nedeniyle yorumlar kısa tutulmuştur.
Modelde kullanılan değişkenler aşağıdaki gibi sıralanabilir:

\begin{tabular}{|c|c|}
\hline RBİST30TL & $\begin{array}{l}\text { TL cinsinden BİST30 endeksi } \\
\text { assırı getiri serisi }\end{array}$ \\
\hline RBİST30USD & $\begin{array}{l}\text { USD cinsinden BISTT30 } \\
\text { endeksi așırı getiri serisi }\end{array}$ \\
\hline ERSP500TL & $\begin{array}{l}\text { : TL cinsinden SP500 endeksi } \\
\text { așırı getiri serisi }\end{array}$ \\
\hline ERSP500USD & $\begin{array}{l}\text { : USD cinsinden SP500 endeksi } \\
\text { aşırı getiri serisi }\end{array}$ \\
\hline YKMSTL & $\begin{array}{l}\text { : TL cinsinden aşırı getirilerle } \\
\text { hesaplanan YKMS serisi }\end{array}$ \\
\hline JKMS & $\begin{array}{l}\text { : USD cinsinden aşırı getirilerle } \\
\text { hesaplanan YKMS serisi }\end{array}$ \\
\hline
\end{tabular}

Tablo 1'de yer alan tanımlayıcı istatistikler genel olarak değerlendirildiğinde hem USD hem TL cinsinden getiri serileri açısından volatilitenin (standart sapma) beklentiler yönünde kriz içeren dönemde yükseldiği, kriz sonrası dönemde ise düştügü görülmüştür. Buna karşın, çarpıklık katsayılarının kriz içeren dönemde düştüğü, kriz sonrası dönemse ise ciddi anlamda arttığı yani asimetrik etkilerin daha baskın hale geldiği anlaşılmıştır. Basıklık katsayıları ise her seri için farklı davranış göstermiştir. ERBIST30TL ve ERBISTT30USD getiri serileri için kriz içeren dönemde az da olsa düşmüş, kriz sonrası dönemde ise görece artmakla birlikte tüm döneme göre daha az olduğu belirlenmiștir. ERSP500USD getiri serisi için basıklık katsayısı hem kriz içeren dönemde hem de kriz sonrası dönemde düşüş göstermesine karşın, ERSP500TL getiri serisi için kriz içeren dönemde düşmekle birlikte kriz sonrası dönemde fazlasıyla artarak tüm döneme göre daha yüksek olmuştur. YKMS için hem TL hem de USD cinsinden elde edilen katsayılar hemen hemen birbiriyle aynıdır. Nitekim matematiksel olarak böyle bir sonuç çıkması doğaldır. Son olarak hem YKMSTL hem de YKMSUSD için kriz içeren dönemde düşmüş, kriz sonrası dönemde ise artarak tüm dönemdeki değerinin de üzerinde bir büyüklüğe ulaşmıştır. Ayrıca, Jarque-Bera test istatistikleri serilerin normal dağılıma uymadıklarını doğrulamıştır. 
Tablo 1. Tanımlayıcı İstatistikler (Tüm Dönem)

\begin{tabular}{ccccccc}
\hline & ERBíST30TL & ERBíST30USD & ERSP500USD & ERSP500TL & YKMSTL & YKMSUSD \\
\hline Ortalama & $-1,61 \mathrm{E}-05$ & $-0,000404$ & 0,000206 & 0,000594 & 0,013384 & 0,013384 \\
En Büyük & 0,126799 & 0,172987 & 0,109497 & 0,153360 & 0,062337 & 0,062337 \\
En Küçük & $-0,109193$ & $-0,152880$ & $-0,094773$ & $-0,110697$ & 0,003434 & 0,003434 \\
Standart Sapma & 0,017234 & 0,019756 & 0,011955 & 0,015087 & 0,004870 & 0,004870 \\
Çarpıklık & $-0,127421$ & $-0,433971$ & $-0,375400$ & 0,460907 & 1,810264 & 1,810557 \\
Basıklık & 6,652146 & 9,906308 & 14,66043 & 14,11279 & 10,12669 & 10,12747 \\
\hline Jarque-Bera & $1.875,32$ & $6.779,02$ & $19.102,72$ & $17.397,76$ & $8.940,38$ & $8.942,53$ \\
Olasılık & 0,000000 & 0,000000 & 0,000000 & 0,000000 & 0,000000 & 0,000000 \\
\hline Gözlem Sayısı & 3358 & 3358 & 3358 & 3358 & 3358 & 3358 \\
\hline
\end{tabular}

(Kriz İçeren Dönem)

\begin{tabular}{ccccccc}
\hline & ERBIST30TL & ERBIST30USD & ERSP500USD & ERSP500TL & YKMSTL & YKMSUSD \\
\hline Ortalama & 0,000205 & 0,000110 & $8,46 \mathrm{E}-05$ & 0,000179 & 0,014400 & 0,014399 \\
En Büyük & 0,126799 & 0,172987 & 0,109497 & 0,141437 & 0,044582 & 0,044582 \\
En Küçük & $-0,097908$ & $-0,152880$ & $-0,094773$ & $-0,110697$ & 0,003434 & 0,003434 \\
Standart Sapma & 0,019204 & 0,021707 & 0,014613 & 0,017097 & 0,005155 & 0,005155 \\
Çarpıklık & $-0,029577$ & $-0,244350$ & $-0,312222$ & 0,242236 & 1,562897 & 1,562897 \\
Basıklık & 6,222973 & 9,629018 & 12,05147 & 11,17223 & 7,103900 & 7,103900 \\
\hline Jarque-Bera & 750,75 & $3.192,20$ & $5.947,55$ & $4.842,20$ & $1.922,76$ & $1.923,23$ \\
Olasılık & 0,000000 & 0,000000 & 0,000000 & 0,000000 & 0,000000 & 0,000000 \\
\hline Gözlem Sayısı & 1734 & 1734 & 1734 & 1734 & 1734 & 1734 \\
\hline
\end{tabular}

(Kriz Sonrası Dönem)

\begin{tabular}{ccccccc}
\hline & ERBİST30TL & ERBİST30USD & ERSP500USD & ERSP500TL & YKMSTL & YKMSUSD \\
\hline Ortalama & 0,000205 & $-0,000953$ & 0,000335 & 0,001037 & 0,012299 & 0,012299 \\
En Büyük & 0,068891 & 0,079976 & 0,048332 & 0,153360 & 0,062337 & 0,062337 \\
En Küçük & $-0,109193$ & $-0,140354$ & $-0,041911$ & $-0,057960$ & 0,004518 & 0,004518 \\
Standart Sapma & 0,014848 & 0,017423 & 0,008221 & 0,012581 & 0,004289 & 0,004289 \\
Çarpıklık & $-0,375918$ & $-0,856438$ & $-0,413823$ & 1,084486 & 2,248292 & 2,248292 \\
Basıklık & 6,364669 & 9,045512 & 7,101067 & 19,60563 & 17,60812 & 17,60812 \\
\hline Jarque-Bera & 804,30 & $2.671,63$ & $1.184,42$ & $18.977,22$ & $15.808,04$ & $15.808,04$ \\
Olasılık & 0,000000 & 0,000000 & 0,000000 & 0,000000 & 0,000000 & 0,000000 \\
\hline Gözlem Sayısı & 1624 & 1624 & 1624 & 1624 & 1624 & 1624 \\
\hline
\end{tabular}

Getiri serileri yüksek frekanslı ve logaritmik birinci dereceden farkları alınarak hesaplandıkları için durağan olacakları bilinse de Augmented Dickey Fuller-ADF, PhillipsPerron-PP ve Kwiatkowski-Phillips-SchmidtShin-KPSS birim kök testleri ile durağanlıkları sınanmıștır.

ADF ve PP birim kök testlerinde, sıfır hipotezi $\left(\mathrm{H}_{0}\right)$ serinin durağan olmadığını buna karşın alternatif hipotez $\left(\mathrm{H}_{1}\right)$ serinin durağan olduğu yönündedir. KPSS birim kök testinde ise, tam tersine sifır hipotezi $\left(\mathrm{H}_{0}\right)$ serinin durağan olduğu buna karşın alternatif hipotez $\left(\mathrm{H}_{1}\right)$ serinin durağan olmadığı yönündedir. Așağıdaki tablodar görüleceği üzere \%99 güven düzeyinde tüm serilerin üç farklı dönemde de I(0) yani düzeyde durağan oldukları görülmüştür. 
Tablo 2. Durağanlık Testi Sonuçları

\begin{tabular}{|c|c|c|c|c|c|c|c|}
\hline $\begin{array}{c}\text { Analiz } \\
\text { Dönemi }\end{array}$ & & ERBISST30TL & ERBÍST30USD & ERSP500USD & ERSP500TL & YKMSTL & YKMSUSD \\
\hline \multirow{3}{*}{$\begin{array}{c}\text { Tüm } \\
\text { Dönem }\end{array}$} & ADF & $-57,21597 b$ & $-3099303^{b}$ & $-44,83704^{c}$ & $-54,14043^{a}$ & $-10,72059 c$ & $-10,72059 c$ \\
\hline & KPSS & $0,038595^{\mathrm{a}}$ & $0,106551^{\mathrm{c}}$ & $0,065885^{c}$ & $0,067085^{a}$ & $0,570917 \mathrm{c}$ & $0,417557 \mathrm{c}$ \\
\hline & PP & $-57,21392^{b}$ & $-48,35708^{c}$ & $-63,35139 c$ & $-65,79853^{b}$ & $-51,79115^{c}$ & $-51,79115^{c}$ \\
\hline \multirow{3}{*}{$\begin{array}{c}\text { Kriz } \\
\text { İçeren } \\
\text { Dönem }\end{array}$} & ADF & $-40,19385^{b}$ & $-22,64630^{b}$ & $-46,21362^{c}$ & $-43,63681^{c}$ & $-9,942870^{c}$ & $-9,939977 \mathrm{c}$ \\
\hline & KPSS & $0,070935^{c}$ & $0,073834 \mathrm{c}$ & $0,242224 \mathrm{a}$ & $0,067635^{b}$ & $0,417050^{c}$ & $0,417557 \mathrm{c}$ \\
\hline & PP & $-40,17734 b$ & $-34,00916^{c}$ & $-46,65373^{b}$ & $-56,76308^{c}$ & $\begin{array}{c}- \\
31,782031^{c}\end{array}$ & $-31,77551^{c}$ \\
\hline \multirow{3}{*}{$\begin{array}{c}\text { Kriz } \\
\text { Sonrası } \\
\text { Dönem }\end{array}$} & ADF & $-18,36169 b$ & $-17,85541^{b}$ & $-19,48208^{c}$ & $-19,15099 b$ & $-10,99960^{a}$ & $-10,99960^{a}$ \\
\hline & KPSS & $0,092386^{a}$ & $0,058534^{b}$ & $0,025250^{\mathrm{a}}$ & $0,033532^{b}$ & $0,451403^{c}$ & $0,451403^{c}$ \\
\hline & PP & $-41,41171^{a}$ & $-34,74090^{c}$ & $-39,81687 b$ & $-39,55881^{c}$ & $-32,83539 c$ & $-32,83539 c$ \\
\hline
\end{tabular}

Not: Birim kök testleri için a sabit terim var ve trend yok, b sabit terim ve trend yok, c sabit terim ve trend var.

Tüm Dönem için: \%99 güven düzeyinde MacKinnon's kritik değerleri ADF testi -3,432111, PP teti -3,432110, KPSS testi -0,739000'dur

Kriz İçeren Dönem için: \%99 güven düzeyinde MacKinnon's kritik değerleri ADF testi -3,433920, PP testi -3,566297 ve KPSS testi -0,739000'dur.

Kriz Sonrası Dönem için: \%99 güven düzeyinde MacKinnon's kritik değerleri ADF testi -3,963722, PP testi -3,963708, KPSS testi -0,739000'dur.

\subsection{Ampirik Bulgular}

Farklı para birimleri cinsinden yatay kesit mutlak sapmaya (YKMS) dayalı olarak S\&P500 endeksi ile BIST30 endeksi arasında finansal bulaşıcılık etkisi ve sürü davranışı varlığının test edilmesi amacıyla öncelikle, en küçük kareler yöntemi (EKKY) kullanılarak yatay kesit mutlak sapma katsayısının teorik uygunluğu incelenmiş, ardından asimetrik GARCH tipi modeller kullanılarak finansal bulaşıcılık etkisi ve sürü davranışı yanında asimetrik etkilerin de varlığı araştırılmıştır.

\subsubsection{Yerel Para Birimi Bazlı Öngörü Sonuçları}

Tüm dönem, kriz içeren dönem ve kriz sonrası dönem için EKKY kullanılarak elde edilen öngörü sonuçları aşağıdaki tabloda yer almaktadır. Tabloya göre finansal bulaşıcılık katsayısı her dönemde pozitif işaret alıp istatistikî ve iktisadi olarak anlamlı çıkmıștır. Buna göre, ERSP500USD'de meydana gelen \%1 oranında bir değişimin ERBIST30TL'de; tüm dönemde \%0,491750, kriz içeren dönemde \%0,503328 ve kriz sonrası dönemde ise \%0,451959 oranında aynı yönlü bir değişime neden olduğu görülmüştür.

Finansal bulaşıcılık katsayısının kriz içeren dönemde en yüksek olduğu bulgulanmıştır. Kriz içeren dönemde hisse senedi piyasalarında oynaklığın daha yüksek olması finansal piyasalar arasındaki etkileșimi daha fazla artırmaktadır. Teknolojik gelişmelere bağlı olarak, bir piyasada oluşan bilginin neredeyse aynı hızla diğer piyasalara aktarımı sonucunda piyasalar ortak hareket etmeye başlamakta ve bu durum uzun dönemde sürü davranışına dönüşebilmektedir.

Tablo 3. EKKY Öngörü Sonuçları (Yerel Para Birimi Bazlı)

\begin{tabular}{|c|c|c|c|}
\hline Katsayı & $\begin{array}{c}\text { (Tüm } \\
\text { Dönem) }\end{array}$ & $\begin{array}{c}\text { (Kriz } \\
\text { İçeren } \\
\text { Dönem) }\end{array}$ & $\begin{array}{c}\text { (Kriz } \\
\text { Sonrası } \\
\text { Dönem) }\end{array}$ \\
\hline C & $\begin{array}{c}0,000445 \\
0,544273 \\
{[0,5863]}\end{array}$ & $\begin{array}{c}-0,001066 \\
(-0,842625) \\
{[0,3996]}\end{array}$ & $\begin{array}{c}0,003033 \\
(2,806322) \\
{[0,0051]}\end{array}$ \\
\hline ERSP500USD & $\begin{array}{c}0,491750 \\
(21,01970) \\
{[0,000]}\end{array}$ & $\begin{array}{c}0,503328 \\
(17,25355) \\
{[0,0000]}\end{array}$ & $\begin{array}{c}0,451959 \\
(10,44453 \\
{[0,0000]}\end{array}$ \\
\hline YKMSTL & $\begin{array}{c}-0,042032 \\
(-0,731897) \\
{[0,4643]}\end{array}$ & $\begin{array}{c}-0,085261 \\
(1,031129) \\
{[0,3026]}\end{array}$ & $\begin{array}{c}-0,279378 \\
(-3,368619) \\
{[0,0008]}\end{array}$ \\
\hline $\mathbf{L L}$ & $9.080,27$ & $4.531,89$ & $4.592,07$ \\
\hline AIC & $-5,406355$ & $-5,223633$ & $-5,647225$ \\
\hline SIC & $-5,400888$ & $-5,214190$ & $-5,637539$ \\
\hline HQC & $-5,404400$ & $-5,220141$ & $-5,643637$ \\
\hline
\end{tabular}

Not: t-istatistikleri parantez içinde, olasılık (probability) değerleri köșeli parantez içinde gösterilmiştir. LL-Log-Olasılık, AIC-Akaike Bilgi Kriteri, SIC-Schwarz Bilgi Kriteri, HQC-Hannan-Quinn Bilgi Kriteri değerlerini göstermektedir.

Finansal Bulaşıcılık Modelinde sürü davranışının varlığı negatif değer alan YKMS değişkeni ile tespit edilir. Yukarıdaki tabloya göre sürü davranışı ile yayılma etkisini gösteren YKMSTL katsayısı sadece kriz sonrası dönemde istatistikî ve iktisadi olarak anlamlı 
çıkmıștır. Buna göre, kriz sonrası dönemde YKMSTL'de meydana gelen \%1 oranında artış ERBIST30TL'de krizin sürü davranışı ile yayılmasinı $\quad \% 0,239720 \quad$ oraninda azaltmaktadır.

EKKY temel varsayımlarından bir tanesi değişkenlerin normal dağılıma $u t \sim \phi\left(0, \sigma^{2}\right)$ uygun olmasıdır. Aksi halde EKKY öngörüleri yanlı sonuç verme eğiliminde olacaktır. Nitekim, Tablo 1'deki tanımlayıcı istatistikler incelendiğinde serilerin normal dağılıma uymadığı anlaşılmaktadır. Bu yüzden, normal dağılım ve sabit varyans esasına dayalı olarak öngörü yapılan EKKY modeline karşın getiri serilerinde koşullu değișen varyansın varlı̆̆ını test etmek üzere ARCH-LM testi yapılmıştır. Üç farklı dönem için de ARCH-LM test istatistiği değerleri $\chi^{2}$ tablo değerlerinden büyük çıktığından, getiri serilerinde koşullu değişen varyans özelliği bulunduğu anlaşılmıștır. Bu yüzden şokların getiri volatilitesi üzerindeki asimetrik etkisini analiz edebilmek ve karșılaștırma yapabilmek için EGARCH, TGARCH ve APGARCH modelleri ile öngörü yapılmıștır.

Model seçim kriterleri olarak Logaritmik Olasılık, Akaike Bilgi Kriteri, Schwarz Bilgi Kriteri ve Hannan-Quinn Bilgi Kriteri dikkate alınmıştır. Tüm dönem ve kriz içeren dönem için Student-t dağılımlı TGARCH modeli ve kriz sonrası dönem için Student-t dağılımlı EGARCH modelinin en anlaml modeller oldukları görülmüştür.

Tablo 4. Asimetrik GARCH Tipi Modellerin Öngörü Sonuçları (Yerel Para Birimi Bazlı)

\begin{tabular}{|c|c|c|c|c|c|c|c|c|c|}
\hline \multirow[b]{2}{*}{ Katsayı } & \multicolumn{3}{|c|}{ EGARCH $(1,1)$ Modeli } & \multicolumn{3}{|c|}{ TGARCH $(1,1)$ Modeli } & \multicolumn{3}{|c|}{ APGARCH(1,1) Modeli } \\
\hline & TD & KID & KSD & TD & KİD & KSD & TD & KİD & KSD \\
\hline C & $\begin{array}{c}-0,000213 \\
(-0,306656) \\
{[0,7591]}\end{array}$ & $\begin{array}{c}-0,001831 \\
(-1,659597) \\
{[0,0970]}\end{array}$ & $\begin{array}{c}0,001300 \\
(1,547749) \\
{[0,1217]}\end{array}$ & $\begin{array}{c}6,44 \mathrm{E}-05 \\
(0,090209) \\
{[0,9281]}\end{array}$ & $\begin{array}{c}-0,001595 \\
(-1,397662) \\
{[0,1622]}\end{array}$ & $\begin{array}{c}0,002064 \\
(2,259936) \\
{[0,0238]}\end{array}$ & $\begin{array}{c}-0,000116 \\
(-0,164116) \\
{[0,8696]}\end{array}$ & $\begin{array}{c}-0,001828 \\
(-1,625101) \\
{[0,1041]}\end{array}$ & $\begin{array}{c}0,001859 \\
(2,044553) \\
{[0,0409]}\end{array}$ \\
\hline ERSP500USD & $\begin{array}{c}0,477355 \\
(21,85083) \\
{[0,0000]}\end{array}$ & $\begin{array}{c}0,501425 \\
(17,81574) \\
{[0,0000]}\end{array}$ & $\begin{array}{c}0,425604 \\
(11,63315) \\
{[0,0000]}\end{array}$ & $\begin{array}{c}0,477873 \\
(21,89064) \\
{[0,0000]}\end{array}$ & $\begin{array}{c}0,505177 \\
(17,64879) \\
{[0,0000]}\end{array}$ & $\begin{array}{c}0,426171 \\
(11,92980) \\
{[0,0000]}\end{array}$ & $\begin{array}{c}0,477891 \\
(21,85680) \\
{[0,0000]}\end{array}$ & $\begin{array}{c}0,503243 \\
(17,68259) \\
{[0,0000]}\end{array}$ & $\begin{array}{c}0,428766 \\
(11,76274) \\
{[0,0000]}\end{array}$ \\
\hline YKMSTL & $\begin{array}{c}0,022078 \\
(0,457433) \\
{[0,6474]}\end{array}$ & $\begin{array}{c}0,166038 \\
(0,0218) \\
{[0,0123]}\end{array}$ & $\begin{array}{c}-0,131680 \\
(-2,192300) \\
{[0,0284]}\end{array}$ & $\begin{array}{c}0,003099 \\
(0,062949) \\
{[0,9498]}\end{array}$ & $\begin{array}{c}0,152262 \\
(2,055935) \\
(0,0398)\end{array}$ & $\begin{array}{c}-0,190030 \\
(-2,854514) \\
(0,0043)\end{array}$ & $\begin{array}{c}0,016064 \\
(21,85680) \\
{[0,0000]}\end{array}$ & $\begin{array}{c}0,167141 \\
(2,283085) \\
{[0,0224]}\end{array}$ & $\begin{array}{c}-0,176898 \\
(-2,675369) \\
{[0,0075]}\end{array}$ \\
\hline $\mathbf{W}_{0}$ & $\begin{array}{c}-0,269669 \\
(-5,567362) \\
{[0,0000]}\end{array}$ & $\begin{array}{c}-0,435549 \\
(-4,761576) \\
{[0,0000]}\end{array}$ & $\begin{array}{c}-0,127038 \\
(-4,142644) \\
{[0,0000]}\end{array}$ & $\begin{array}{c}5,15 \mathrm{E}-06 \\
(4,118793) \\
{[0,000]}\end{array}$ & $\begin{array}{c}9,52 \mathrm{E}-06 \\
(3,496159) \\
{[0,0005]}\end{array}$ & $\begin{array}{c}2,24 \mathrm{E}-06 \\
(3,333846) \\
{[0,0009]}\end{array}$ & $\begin{array}{c}3,65 \mathrm{E}-05 \\
(0,797924) \\
{[0,4249]}\end{array}$ & $\begin{array}{c}0,000159 \\
(0,686353) \\
{[0,4925]}\end{array}$ & $\begin{array}{c}7,98 \mathrm{E}-05 \\
(0,587624) \\
{[0,5568]}\end{array}$ \\
\hline$\alpha$ & $\begin{array}{c}0,113827 \\
6,783585 \\
{[0,0000]}\end{array}$ & $\begin{array}{c}0,165900 \\
(5,688740) \\
{[0,0000]}\end{array}$ & $\begin{array}{c}0,019876 \\
(1,391109) \\
{[0,1642]}\end{array}$ & $\begin{array}{c}0,021708 \\
(2,455540) \\
{[0,0141]}\end{array}$ & $\begin{array}{c}0,035768 \\
(2,212668) \\
{[0,269]}\end{array}$ & $\begin{array}{c}-0,011329 \\
(-1,383063) \\
{[0,1666]}\end{array}$ & $\begin{array}{c}0,056211 \\
(4,923716) \\
{[0,0000]}\end{array}$ & $\begin{array}{c}0,086644 \\
(4,760643) \\
{[0,0000]}\end{array}$ & $\begin{array}{c}0,021814 \\
(3,201253) \\
{[0,0014]}\end{array}$ \\
\hline$\beta$ & $\begin{array}{c}0,978317 \\
194,1088 \\
{[0,0000]}\end{array}$ & $\begin{array}{c}0,962822 \\
(98,11508) \\
{[0,0000]}\end{array}$ & $\begin{array}{c}0,981140 \\
(310,1286) \\
{[0,0000]}\end{array}$ & $\begin{array}{c}0,925470 \\
(85,38305) \\
{[0,000]}\end{array}$ & $\begin{array}{c}0,887139 \\
(45,3661) \\
{[0.0000]}\end{array}$ & $\begin{array}{c}0,972529 \\
(123,8986) \\
{[0,0000]}\end{array}$ & $\begin{array}{c}0,925821 \\
(85,62461) \\
{[0,0000]}\end{array}$ & $\begin{array}{c}0,886723 \\
(44,52678) \\
{[0,0000]}\end{array}$ & $\begin{array}{l}0,968359 \\
134,4847 \\
{[0,0000]}\end{array}$ \\
\hline$\gamma$ & $\begin{array}{c}-0,058227 \\
(-5,521579) \\
{[0,0000]}\end{array}$ & $\begin{array}{c}-0,077089 \\
(-3,629506) \\
{[0,0000]}\end{array}$ & $\begin{array}{c}-0,059197 \\
(-5,207694) \\
{[0,0000]}\end{array}$ & $\begin{array}{c}0,062730 \\
(4,715584) \\
{[0,000]}\end{array}$ & $\begin{array}{c}0,086465 \\
(3,570106) \\
{[0,0004]}\end{array}$ & $\begin{array}{c}0,051736 \\
(4,303252) \\
{[0,000]}\end{array}$ & $\begin{array}{c}0,414524 \\
(3,745040) \\
{[0,0002]}\end{array}$ & $\begin{array}{c}0,428182 \\
(3,161598) \\
{[0,0016]}\end{array}$ & $\begin{array}{c}0,999974 \\
4,8 \mathrm{E}+103 \\
{[0,0000]}\end{array}$ \\
\hline$\delta$ & - & - & - & - & - & - & $\begin{array}{c}1,544748 \\
(5,419421) \\
{[0,0000]} \\
\end{array}$ & $\begin{array}{c}1,347114 \\
(3,943514) \\
{[0,0001]}\end{array}$ & $\begin{array}{c}1,169148 \\
(3,108978) \\
{[0,0019]}\end{array}$ \\
\hline LL & $9.395,34$ & $4.707,05$ & $4.710,73$ & $9.396,27$ & $4.707,54$ & $4.707,25$ & $9.397,32$ & $4.708,29$ & $4.708,86$ \\
\hline AIC & $-5,591030$ & $-5,419896$ & $-5,791533$ & $-5,591583$ & $-5,420461$ & $-5,787250$ & $-5,591614$ & $-5,420170$ & $-5,788002$ \\
\hline SIC & $-5,576452$ & $-5,394714$ & $-5,764968$ & $-5,577005$ & $-5,395279$ & $-5,760686$ & $-5,575213$ & $-5,391840$ & $-5,758117$ \\
\hline HQC & $-5,585816$ & $-5,410583$ & $-5,781676$ & $-5,586370$ & $-5,411148$ & $-5,777393$ & $-5,585748$ & $-5,409692$ & $-5,776913$ \\
\hline ARCH-LM & $\begin{array}{c}0,040436 \\
(0,8406)\end{array}$ & $\begin{array}{c}0,028954 \\
(0,8649)\end{array}$ & $\begin{array}{c}0,490389 \\
(0,4838)\end{array}$ & $\begin{array}{c}0,410138 \\
(0,5219)\end{array}$ & $\begin{array}{c}0,008311 \\
(0,9274)\end{array}$ & $\begin{array}{c}0,302787 \\
(0,5821)\end{array}$ & $\begin{array}{c}0,170863 \\
(0,6793)\end{array}$ & $\begin{array}{c}0,003191 \\
(0,9550)\end{array}$ & $\begin{array}{l}0,606827 \\
(0,4375)\end{array}$ \\
\hline$Q(10)$ & $\begin{array}{l}14,305 \\
(0,160)\end{array}$ & $\begin{array}{c}7,7883 \\
(0,650)\end{array}$ & $\begin{array}{l}18,161 \\
(0,052)\end{array}$ & $\begin{array}{l}14,135 \\
(0,160)\end{array}$ & $\begin{array}{l}8,5531 \\
(0,575)\end{array}$ & $\begin{array}{c}17,911 \\
(0,5821)\end{array}$ & $\begin{array}{l}14,105 \\
(0,168)\end{array}$ & $\begin{array}{l}7,8720 \\
(0,641)\end{array}$ & $\begin{array}{l}19,394 \\
(0,036)\end{array}$ \\
\hline$Q^{2}(10)$ & $\begin{array}{r}13,458 \\
(0,199) \\
\end{array}$ & $\begin{array}{c}6,6944 \\
(0,754)\end{array}$ & $\begin{array}{c}13,583 \\
(0,193)\end{array}$ & $\begin{array}{c}13,192 \\
(0,176)\end{array}$ & $\begin{array}{l}5,8449 \\
(0,828)\end{array}$ & $\begin{array}{l}8,7106 \\
(0,560)\end{array}$ & $\begin{array}{l}11,735 \\
(0,303)\end{array}$ & $\begin{array}{r}6,5694 \\
(0,765) \\
\end{array}$ & $\begin{array}{l}11,100 \\
(0,350)\end{array}$ \\
\hline
\end{tabular}

Not: TD: Tüm Dönem, KİD: Kriz İçeren Dönem, KSD: Kriz Sonrası Dönem. z-istatistikleri parantez içinde, olasılık (probability) değerleri köşeli parantez içinde gösterilmiştir. LL-Log-Olasılık, AIC-Akaike Bilgi Kriteri, SIC-Schwarz Bilgi Kriteri, HQC-Hannan-Quinn Bilgi Kriteri değerlerini göstermektedir. ARCH-LM 1 gecikmeli ARCH test istatistiğini, Q(10) ve Q2(10) sırasıyla standardize edilmiş ve karesi alınmış hataların test istatistiklerini (Ljung-Box) göstermektedir. Parantez içindeki değerler gecikmelerini vermektedir. 


\section{D. ÖZDEN - M. URAL}

Tablo 4'e göre; tüm dönem ve kriz içeren dönem dikkate alındığında TGARCH modeli itibarıyla ortalama denkleminde finansal bulaşıcılık katsayısı istatistiki ve iktisadi olarak anlamlı olup ERSP500USD'de meydana gelen \%1 oranında değişimin ERBIST30TL'de, tüm dönemde \%0,477873 oranında, kriz içeren dönemde ise \%0,505177 oranında aynı yönlü bir değișime neden olduğu görülmüştür. Sürü davranışının varlığını temsil eden YKMSTL katsayısı tüm dönem ve kriz içeren dönemde pozitif ve anlamsız bulunduğundan ilgili dönemlerde sürü davranışının olmadığı şeklinde yorumlanmaktadır. Bununla birlikte, 2008 küresel finans krizinin kriz içeren dönemde sürü davranışı ile yayılmadığı da vurgulanmalıdır. Varyans denklemine göre, tüm dönem ve kriz içeren dönem için TGARCH modelinde $\alpha$ katsayısı sadece tüm dönem için anlamlı çlkmıştır. Getiri serisine gelen şokların hafızada kalma süresini gösteren $\beta$ katsayısı 1 yakın olup şokların uzun süre hafızada kaldığını ve gecikmeli olarak ortalamaya döndügünü ifade etmektedir. Asimetri katsayısı $\gamma$, tüm dönem ve kriz içeren dönem için pozitif ve anlamlı bulunmuştur. $\mathrm{Bu}$ durumda seriye gelen negatif şokların (olumsuz haberlerin) BIST30 endeksi volatilitesi üzerinde daha fazla etkiye sahip olduğu anlaşılmıştır. Model kurulumu gereği TGARCH ve EGARCH modellerinin asimetri katsayıları birbirinin tersi işaretlere sahip olup aynı yönde yorumlanmaktadır. Artıklarda halen ARCH etkisinin varlığını incelemek üzere yapılan ARCH-LM test istatistiği değerleri, $\chi^{2}$ tablo değerlerinden küçük olup anlamsız çıkmıştır. Bu durumda, artıklarda (hata terimlerinde) ARCH etkisinin kalmadığ anlaşılmıştır. Ayrıca Ljung-Box istatistikleri itibarıyla standartlaştırılmış ve kareli standartlaştırılmış artıklarda seri korelasyon kalmadığı görülmüştür.

Yine Tablo 4'te kriz sonrası dönem dikkate alındığında daha anlamlı bulunan EGARCH modeli itibarıyla ortalama denkleminde finansal bulaşıcılık katsayısı istatistiki ve iktisadi olarak anlaml bulunmuştur. Buna göre ERSP500USD'de meydana gelen \%1 oranında değişimin ERBIST30TL'de $\% 0,425604$ oranında aynı yönlü bir değişime neden olduğu görülmüştür. Bunun yanında, krizin sürü davranışı ile yayılma etkisini gösteren YKMSTL katsayısının işareti negatif olup istatistiki ve iktisadi olarak anlaml bulunmuştur. Buna göre, YKMSTL'de meydana gelen \%1 oranında azalma ERBIST30TL'de krizin sürü davranışı ile yayılmasını $\% 0,131680$ oranında artırmaktadır. Varyans denklemine göre ise, kriz sonrası dönem için EGARCH modelinde (TGARCH modelinde de aynı şekilde) $\alpha$ katsayısı anlamsız çıkmıștır. Getiri serisine gelen şokların hafızada kalma süresini gösteren $\beta$ katsayısı 1 yakın olup şokların uzun süre hafızada kaldığını ifade etmektedir. Nitekim $\beta$ katsayısı tüm dönem ve kriz içeren döneme göre daha da yüksek bulunmuştur. Asimetri katsayısı $\gamma$, kriz sonrası dönem için negatif (TGARCH modelinde de pozitif) ve anlamlı bulunmuştur. Bu durumda seriye gelen negatif şokların (olumsuz haberlerin) BİST30 endeks oynaklığını daha fazla artırdığı anlaşılmıştır. Kriz sonrası dönemde asimetri katsayısının beklendiği üzere kriz içeren döneme göre düştüğü gözlenmiştir. ARCH-LM test istatistiği itibarıla artıklarda (hata terimlerinde) ARCH etkisinin kalmadığı anlaşılmıştır. Ayrıca LjungBox istatistikleri itibarıyla standartlaştırılmış ve kareli standartlaştırılmış artıklarda seri korelasyon kalmadığı görülmüştür.

\subsubsection{USD Bazlı Öngörü Sonuçları}

Tüm dönem, kriz içeren dönem ve kriz sonrası dönem için EKKY kullanılarak elde edilen öngörü sonuçları Tablo 5'te yer almaktadır.

Tablo 5'e göre finansal bulaşıcılık katsayısı her dönemde pozitif işaret alıp istatistikî ve iktisadi olarak anlamlı çıkmıştır. Buna göre, ERSP500USD'de meydana gelen \%1 oranında değişim ERBIST30USD'de; tüm dönemde $\% 0,495574$, kriz içeren dönemde $\% 0,510353$ ve kriz sonrası dönemde ise \%0,445157 oranında aynı yönlü bir değişime neden olmaktadır. Finansal bulaşıcılık katsayısının beklendiği üzere kriz içeren dönemde en yüksek olduğu bulgulanmıştır. 
Sürü davranışı ile yayılma etkisini gösteren YKMSUSD katsayısı hem tüm dönem hem de kriz sonrası dönemde negatif işaret alıp istatistikî ve iktisadi olarak anlamlı çıkmıștır. Ancak kriz içeren dönemde negatif bir değer almasına karşın istatistiki olarak anlamsız çıkmıştır. Buna göre, YKMSUSD'de meydana gelen \%1 oranında azalma ERBIST30USD'de krizin sürü davranışı ile yayılmasını tüm dönemde \%0,206743 oranında, kriz sonrası dönemde ise $\% 0,618421$ oranında artırmaktadır.

Tablo 5. EKKY Öngörü Sonuçları (USD Bazlı)

\begin{tabular}{ccccc}
\hline \multirow{2}{*}{ Katsayı } & & $\begin{array}{c}\text { (Tüm } \\
\text { Dönem) }\end{array}$ & $\begin{array}{c}\text { (Kriz } \\
\text { İçeren } \\
\text { Dönem) }\end{array}$ & $\begin{array}{c}\text { (Kriz } \\
\text { Sonrası } \\
\text { Dönem) }\end{array}$ \\
\cline { 1 - 4 } C & & 0,002261 & 0,000112 & 0,006504 \\
& & $(2,379525)$ & $(0,077263)$ & $(5,125391)$ \\
& & {$[0,0020]$} & {$[0,9384]$} & {$[0,0000]$} \\
& & 0,495574 & 0,510353 & 0,445157 \\
ERSP500USD & & $(18,23701)$ & $(15,21991)$ & $(8,761209)$ \\
& & {$[0,0000]$} & {$[0,0000]$} & {$[0,0000]$} \\
& & $-0,206743$ & $-0,003155$ & $-0,618421$ \\
YKMSUSD & & $(-3,099309)$ & $(-0,033194)$ & $(-6,350475)$ \\
& & {$[0,0020]$} & {$[0,9735]$} & {$[0,0000]$} \\
\cline { 3 - 5 } LL & & $8.577,40$ & $4.290,39$ & $4.331,29$ \\
AIC & & $-5,106849$ & $-4,945083$ & $-5,330402$ \\
SIC & & $-5,101382$ & $-4,941590$ & $-5,320441$ \\
HQC & & $-5,104894$ & $-4,941590$ & $-5,326706$ \\
\hline
\end{tabular}

Not: t-istatistikleri parantez içinde, olasılık (probability) değerleri köşeli parantez içinde gösterilmiştir, LL-Log-Olasılık, AIC-Akaike Bilgi Kriteri, SIC-Schwarz Bilgi Kriteri, HQC-Hannan-Quinn Bilgi Kriteri değerlerini göstermektedir.

Daha önce açıklandığı üzere, üç farklı dönem için de ARCH-LM test istatistiklerinden hareketle EGARCH, TGARCH ve APGARCH modelleri ile öngörü yapılmıştır. Aynı şekilde, model seçim kriterlerine göre tüm dönem ve kriz içeren dönem için Student-t dağılımlı TGARCH modeli ve kriz sonrası dönem için Student-t dağılımlı EGARCH modelinin en anlamlı modeller oldukları görülmüştür.

Tablo 6'ya göre; tüm dönem ve kriz içeren dönem için TGARCH modeli ortalama denkleminde finansal bulaşıcılık katsayısı istatistiki ve iktisadi olarak anlaml olup. ERSP500USD'de meydana gelen \%1 oranında değişimin ERBIST30USD'de tüm dönemde $\% 0,478130$ oranında, kriz içeren dönemde ise \%0,497739 oranında aynı yönlü bir değişime neden olduğu görülmüştür. Kriz içeren dönemde finansal bulașıcılık katsayısının yine daha yüksek olduğu görülmektedir. Sürü davranışının varlığını temsil eden YKMSUSD katsayısının işareti tüm dönemde negatif olmakla birlikte $\% 5$ düzeyinde istatistiki olarak anlamsız, kriz içeren dönemde ise $\% 10$ düzeyinde istatistiki olarak anlamlı olmasına karşın işareti pozitif olup iktisadi olarak anlamsızdır. Buna göre, tüm dönem ve kriz içeren dönemde sürü davranışı yoktur. Bu durumda, 2008 küresel finans krizinin kriz içeren dönemde sürü davranışı ile yayılmadığı söylenebilir.

Varyans denklemine göre, TGARCH modelinde $\alpha$ katsayısı tüm dönem ve kriz içeren dönem için anlamlı çıkmıştır. Getiri serisine gelen şokların hafızada kalma süresini gösteren $\beta$ katsayısı ise 1 yakın olup şokların uzun süre hafızada kaldığını ve gecikmeli olarak ortalamaya döndüğünü ifade etmektedir. Asimetri katsayısı $\gamma$, tüm dönem ve kriz içeren dönem için pozitif ve anlamlı bulunmuştur. $\mathrm{Bu}$ durumda seriye gelen negatif şokların (olumsuz haberlerin) volatilite üzerinde daha fazla etkiye sahip olduğu anlaşılmıştır. Artıklarda halen ARCH etkisinin varlığını incelemek üzere hesaplanan ARCH-LM test istatistiği değerleri, $\chi^{2}$ tablo değerlerinden büyük olduğu için artıklarda (hata terimlerinde) ARCH etkisinin kalmadığ anlaşılmıştır. Ayrıca Ljung-Box istatistikleri itibarıyla standartlaştırılmış artıklarda 10 gecikme için seri korelasyon bulunsa da kareli standartlaştırılmış artıklarda seri korelasyon kalmadığı görülmüştür.

Yine Tablo 6'da kriz sonrası dönem dikkate alındığında daha anlamlı bulunan EGARCH modeli itibariyla ortalama denkleminde finansal bulaşıcılık katsayısı istatistiki ve iktisadi olarak anlaml bulunmuştur. Buna göre ERSP500USD'de meydana gelen \%1 oranında değişimin ERBIST30USD'de $\% 0,426815$ oranında aynı yönlü bir değişime neden olduğu görülmüştür. Bunun yanında, krizin sürü davranışı ile yayılma etkisini gösteren YKMSUSD katsayısının işareti beklendiği gibi negatif olup istatistiki ve 
iktisadi olarak anlamlı bulunmuștur. Buna göre, YKMSUSD değişkeninde meydana gelen $\% 1$ oraninda azalma ERBIST30USD değişkeninde krizin sürü davranıșı ile yayılmasını oranında artırmaktadır. Varyans denklemine göre, kriz sonrası dönem için TGARCH modelinin aksine EGARCH modelinde $\alpha$ katsayısı anlamsız çıkmıştır. Getiri serisine gelen şokların hafızada kalma süresini gösteren $\beta$ katsayısı TGARCH modeline göre daha fazla 1 yakın olup şokların uzun süre hafızada kaldığını ifade etmektedir. Nitekim $\beta$ katsayısı tüm dönem ve kriz içeren döneme göre daha da yüksek bulunmuştur. Asimetri katsayısı $\gamma$, kriz sonrası dönem için negatif (TGARCH modelinde de pozitif) ve anlamlı bulunmuștur. Bu durumda seriye gelen negatif şokların (olumsuz haberlerin) BİST30 endeks oynaklığını daha fazla artırdığı anlaşılmıştır. Kriz sonrası dönemde asimetri katsayısının beklendiği üzere kriz içeren döneme göre düștüğü görülmüştür. ARCH-LM test istatistiği itibarıyla artıklarda (hata terimlerinde) ARCH etkisinin halen devam ettiği anlașılmıștır. Bunun yanında Ljung-Box istatistikleri itibarıyla standartlaştırılmış ve kareli standartlaştırılmış artıklarda yine seri korelasyon bulunduğu görülmüştür. Bunun üzerine modelde gecikme sayıları artırılmıș ancak bu durumda ilave gecikmeli ARCH ve GARCH katsayıları anlamsız hale gelmiştir.

Tablo 6. Asimetrik GARCH Tipi Modellerin Öngörü Sonuçları (USD Bazlı)

\begin{tabular}{|c|c|c|c|c|c|c|c|c|c|}
\hline \multirow[b]{2}{*}{ Katsayı } & \multicolumn{3}{|c|}{ EGARCH(1,1) Modeli } & \multicolumn{3}{|c|}{ TGARCH(1,1) Modeli } & \multicolumn{3}{|c|}{ APGARCH(1,1) Modeli } \\
\hline & TD & KİD & KSD & TD & KID & KSD & TD & KiD & KSD \\
\hline C & $\begin{array}{c}0,000151 \\
(0,185917) \\
{[0,8525]}\end{array}$ & $\begin{array}{c}-0,000979 \\
(-0,791200) \\
{[0,4288]}\end{array}$ & $\begin{array}{c}0,002836 \\
(2,629454) \\
{[0,0086]}\end{array}$ & $\begin{array}{c}0,000369 \\
(0,452508) \\
{[0,6509]}\end{array}$ & $\begin{array}{c}-0,001113 \\
(-0,884627) \\
{[0,3764]}\end{array}$ & $\begin{array}{c}0,0003161 \\
(2,890864) \\
{[0,0038]}\end{array}$ & $\begin{array}{c}0,000278 \\
(0,340585) \\
{[0,7334]}\end{array}$ & $\begin{array}{c}-0,001124 \\
(-0,894671) \\
{[0,3710]}\end{array}$ & $\begin{array}{c}0,003395 \\
(3,112842)\end{array}$ \\
\hline ERSP500USD & $\begin{array}{c}0,473240 \\
(19,30158) \\
{[0,0000]}\end{array}$ & $\begin{array}{c}0,495963 \\
(15,89715) \\
{[0,0000]}\end{array}$ & $\begin{array}{c}0,426815 \\
(10,03032) \\
{[0,0000]}\end{array}$ & $\begin{array}{c}0,478130 \\
(19,39651) \\
{[0,0000]}\end{array}$ & $\begin{array}{c}0,497739 \\
(15,79817) \\
{[0,0000]}\end{array}$ & $\begin{array}{c}0,438001 \\
(10,41161) \\
{[0,0000]}\end{array}$ & $\begin{array}{c}0,476190 \\
(19,29750) \\
{[0,0000]}\end{array}$ & $\begin{array}{c}0,495884 \\
(15,74036) \\
{[0,0000]}\end{array}$ & $\begin{array}{c}0,427613 \\
(9,989059) \\
{[0,0000]}\end{array}$ \\
\hline YKMSUSD & $\begin{array}{c}-0,012156 \\
(-0,213867) \\
{[0,8307]}\end{array}$ & $\begin{array}{c}0,122054 \\
(1,482836) \\
{[0,1381]}\end{array}$ & $\begin{array}{c}-0,296235 \\
(-3,707089) \\
{[0,0002]}\end{array}$ & $\begin{array}{c}-0,023114 \\
(-0,406795) \\
{[0,6842]}\end{array}$ & $\begin{array}{c}0,137146 \\
(1,657797) \\
{[0,0974]}\end{array}$ & $\begin{array}{c}-0,316037 \\
(-3,899935) \\
{[0,0000]}\end{array}$ & $\begin{array}{c}-0,017420 \\
(-0,306145) \\
{[0,7595]}\end{array}$ & $\begin{array}{c}0,135841 \\
(1,640480) \\
{[0,1009]}\end{array}$ & $\begin{array}{c}-0,343203 \\
(-4,231688) \\
{[0,0000]}\end{array}$ \\
\hline $\mathbf{w}_{0}$ & $\begin{array}{c}-0,448314 \\
(-6,415105) \\
{[0,0000]}\end{array}$ & $\begin{array}{c}-0,425410 \\
(-5,120845) \\
{[0,0000]}\end{array}$ & $\begin{array}{c}-0,109858 \\
(-3,416899) \\
{[0,0006]}\end{array}$ & $\begin{array}{c}1,56 \mathrm{E}-05 \\
(5,153247) \\
{[0,0000]}\end{array}$ & $\begin{array}{c}1,35 \mathrm{E}-05 \\
(3,754195) \\
{[0,0002]}\end{array}$ & $\begin{array}{c}1,56 \mathrm{E}-05 \\
(3,332660) \\
{[0,0002]}\end{array}$ & $\begin{array}{c}6,78 \mathrm{E}-05 \\
(0,928159) \\
{[0,3533]}\end{array}$ & $\begin{array}{c}8,74 \mathrm{E}-05 \\
(0,671703) \\
{[0,5018]}\end{array}$ & $\begin{array}{c}5,07 \mathrm{E}-05 \\
(0,747953) \\
{[0,4545]}\end{array}$ \\
\hline$\alpha$ & $\begin{array}{c}0,169720 \\
(8,046480) \\
{[0,0000]}\end{array}$ & $\begin{array}{c}0,185342 \\
(6,284695) \\
{[0,0000]}\end{array}$ & $\begin{array}{c}0,031989 \\
(2,156941) \\
{[0,0310]}\end{array}$ & $\begin{array}{c}0,045573 \\
(3,267410) \\
{[0,0011]}\end{array}$ & $\begin{array}{c}0,044417 \\
(2,335638) \\
{[0,0195]}\end{array}$ & $\begin{array}{c}0,023781 \\
(1,520640) \\
{[0,1284]}\end{array}$ & $\begin{array}{c}0,089847 \\
(5,963490) \\
{[0,0000]}\end{array}$ & $\begin{array}{c}0,096805 \\
(4,830338) \\
{[0,0000]}\end{array}$ & $\begin{array}{c}0,017713 \\
(3,071079) \\
{[0,0021]}\end{array}$ \\
\hline$\beta$ & $\begin{array}{c}0,961123 \\
(106,5837) \\
{[0,0000]}\end{array}$ & $\begin{array}{c}0,965005 \\
(106,5837) \\
{[0,0000]}\end{array}$ & $\begin{array}{c}0,989893 \\
(296,2393) \\
{[0,0000]}\end{array}$ & $\begin{array}{c}0,858312 \\
(47,62652) \\
{[0,0000]}\end{array}$ & $\begin{array}{c}0,866256 \\
(41,46047) \\
{[0,0000]}\end{array}$ & $\begin{array}{c}0,878578 \\
(33,00330) \\
{[0,0000]}\end{array}$ & $\begin{array}{c}0,869056 \\
(50,82721) \\
{[0,0000]}\end{array}$ & $\begin{array}{c}0,872842 \\
(42,15440) \\
{[0,0000]}\end{array}$ & $\begin{array}{c}0,970808 \\
(160,9032) \\
{[0,0000]}\end{array}$ \\
\hline$\gamma$ & $\begin{array}{c}-0,064218 \\
(-5,925215) \\
{[0,0000]}\end{array}$ & $\begin{array}{c}-0,068015 \\
(-4,356109) \\
{[0,0000]}\end{array}$ & $\begin{array}{c}-0,042833 \\
(-5,110945) \\
{[0,0000]}\end{array}$ & $\begin{array}{c}0,089461 \\
(4,951892) \\
{[0,0000]}\end{array}$ & $\begin{array}{c}0,098719 \\
(3,978294) \\
{[0,0001]}\end{array}$ & $\begin{array}{c}0,072800 \\
(3,322351) \\
{[0,0009]}\end{array}$ & $\begin{array}{c}0,312174 \\
(4,102912) \\
{[0,0000]}\end{array}$ & $\begin{array}{c}0,331226 \\
(3,160416) \\
{[0,0016)}\end{array}$ & $\begin{array}{c}0,999936 \\
(4,8 \mathrm{E}+103) \\
{[0,0000]}\end{array}$ \\
\hline$\delta$ & - & - & - & - & - & - & $\begin{array}{c}1,618661 \\
(6,089444) \\
{[0,0000]} \\
\end{array}$ & $\begin{array}{c}1,536108 \\
(4,173212) \\
{[0,0000]}\end{array}$ & $\begin{array}{c}1,296142 \\
(4,092484) \\
{[0,0000]}\end{array}$ \\
\hline LL & $8.977,30$ & $4.538,09$ & $4.457,22$ & $8.980,04$ & $4.539,17$ & $4.454,22$ & $8.981,03$ & $4.540,00$ & $4.457,34$ \\
\hline AIC & $-5,342050$ & $-5,225023$ & $-5,479344$ & $-5,343682$ & $-5,226265$ & $-5,475650$ & $-5,343680$ & $-5,226076$ & $-5,478255$ \\
\hline SIC & $-5,327472$ & $-5,199841$ & $-5,452779$ & $-5,321904$ & $-5,201084$ & $-5,449085$ & $-5,327280$ & $-5,197746$ & $-5,448370$ \\
\hline HQC & $-5,336836$ & $-5,215710$ & $-5,469487$ & $-5,338468$ & $-5,216952$ & $-5,465793$ & $-5,337814$ & $-5,215598$ & $-5,467166$ \\
\hline ARCH-LM & $\begin{array}{c}2.208324 \\
(0,1377)\end{array}$ & $\begin{array}{c}1,826215 \\
(0,1766)\end{array}$ & $\begin{array}{c}13,81174 \\
(0,0002)\end{array}$ & $\begin{array}{c}0,211047 \\
(0,6459)\end{array}$ & $\begin{array}{c}0,662181 \\
(0,4158)\end{array}$ & $\begin{array}{c}9,902091 \\
(0,0017)\end{array}$ & $\begin{array}{c}1,032150 \\
(0,3097)\end{array}$ & $\begin{array}{c}1,031350 \\
(0,3098)\end{array}$ & $\begin{array}{l}11,16611 \\
(0,0008)\end{array}$ \\
\hline$Q(10)$ & $\begin{array}{l}74,837 \\
(0,000)\end{array}$ & $\begin{array}{c}34,614 \\
(0,000)\end{array}$ & $\begin{array}{l}37,477 \\
(0,000)\end{array}$ & $\begin{array}{l}71,307 \\
(0,000)\end{array}$ & $\begin{array}{l}35,469 \\
(0,000)\end{array}$ & $\begin{array}{l}35,862 \\
(0,000)\end{array}$ & $\begin{array}{l}73,518 \\
(0,000)\end{array}$ & $\begin{array}{l}35,496 \\
(0,000)\end{array}$ & $\begin{array}{l}37,590 \\
(0,000)\end{array}$ \\
\hline$Q^{2}(10)$ & $\begin{array}{r}94,593 \\
(0,459) \\
\end{array}$ & $\begin{array}{l}9,8911 \\
(0,450) \\
\end{array}$ & $\begin{array}{l}28,510 \\
(0,001) \\
\end{array}$ & $\begin{array}{r}7,4296 \\
(0,684) \\
\end{array}$ & $\begin{array}{l}9,0689 \\
(0,526)\end{array}$ & $\begin{array}{l}22,084 \\
(0,015)\end{array}$ & $\begin{array}{c}8,0939 \\
(0,620)\end{array}$ & $\begin{array}{r}8,2359 \\
(0,606)\end{array}$ & $\begin{array}{c}23,214 \\
(0,010)\end{array}$ \\
\hline
\end{tabular}

Not: TD: Tüm Dönem, KİD: Kriz İçeren Dönem, KSD: Kriz Sonrası Dönem. z-istatistikleri parantez içinde, olasılık (probability) değerleri köşeli parantez içinde gösterilmiştir. LL-Log-Olasılık, AIC-Akaike Bilgi Kriteri, SIC-Schwarz Bilgi Kriteri, HQC-Hannan-Quinn Bilgi Kriteri değerlerini göstermektedir. ARCH-LM 1 gecikmeli ARCH test istatistiğini, Q(10) ve Q2(10) sırasıyla standardize edilmiş ve karesi alınmış hataların test istatistiklerini (Ljung-Box) göstermektedir. Parantez içindeki değerler gecikmelerini vermektedir. 


\subsubsection{TL Bazlı Öngörü Sonuçları}

Tüm dönem, kriz içeren dönem ve kriz sonrası dönem için EKKY kullanılarak elde edilen öngörü sonuçları Tablo 7'de yer almaktadır.

Tablo 7'ye göre finansal bulaşıcılık katsayısı her dönemde pozitif işaret alıp istatistikî ve iktisadi olarak anlamlı çıkmıştır. Buna göre, ERSP500TL'de meydana gelen \%1 oraninda değişim ERBIST30TL'de, tüm dönemde $\% 0,294414$ oranında, kriz içeren dönemde $\% 0,332071$ oranında ve kriz sonrası dönemde ise \%0,230021 oranında aynı yönlü bir değişime neden olmaktadır. Yine finansal bulaşıcılık katsayısının kriz içeren dönemde en yüksek olduğu görülmüştür.

Sürü davranışı ile yayılma etkisini gösteren YKMSTL katsayısı üç dönem için de beklendiği üzere negatif işaret almasına karşın, \%10 düzeyinde tüm dönemde ve $\% 5$ düzeyinde sadece kriz sonrası dönemde istatistiki ve iktisadi olarak anlaml bulunmuştur. Buna göre, YKMSTL'de meydana gelen \%1 oranında azalma ERBIST30TL'de krizin sürü davranıșı ile yayılmasını tüm dönemde \%0,97895 oranında ve kriz sonrası dönemde \%0,368314 oranında artırmaktadır.

Tablo 7. EKKY Öngörü Sonuçları (TL Bazlı)

\begin{tabular}{|c|c|c|c|}
\hline Katsayı & $\begin{array}{c}\text { (Tüm } \\
\text { Dönem) }\end{array}$ & $\begin{array}{c}\text { (Kriz } \\
\text { İçeren } \\
\text { Dönem) }\end{array}$ & $\begin{array}{c}\text { (Kriz } \\
\text { Sonrası } \\
\text { Dönem) }\end{array}$ \\
\hline C & $\begin{array}{c}0,001119 \\
(0,294414) \\
{[0,1833]}\end{array}$ & $\begin{array}{c}-0,000604 \\
(12,87584) \\
{[0,6444]}\end{array}$ & $\begin{array}{c}0,004040 \\
(3,683542) \\
{[0,0002]}\end{array}$ \\
\hline ERSP500TL & $\begin{array}{c}0,294414 \\
(15,43829) \\
{[0,0000]}\end{array}$ & $\begin{array}{c}0,332071 \\
(12,87584) \\
{[0,0000]}\end{array}$ & $\begin{array}{c}0,230021 \\
(7,991408) \\
{[0,0000]}\end{array}$ \\
\hline YKMSTL & $\begin{array}{c}-0,097895 \\
(-1,657107) \\
{[0,0976]}\end{array}$ & $\begin{array}{c}-0,052010 \\
(0,608106) \\
{[0,5432]}\end{array}$ & $\begin{array}{c}-0,368314 \\
(-4,362686) \\
{[0,0000]}\end{array}$ \\
\hline LL & $8.987,784$ & $4.473,605$ & $4.570,557$ \\
\hline AIC & $-5,351271$ & $-5,156407$ & $-5,615109$ \\
\hline SIC & $-5,345804$ & $-5,146964$ & $-5,621374$ \\
\hline HQC & $-5,349316$ & $-5,152915$ & $-5,326706$ \\
\hline
\end{tabular}

Not: t-istatistikleri parantez içinde, olasıllk (probability) değerleri köşeli parantez içinde gösterilmiştir, LL-Log-Olasılık, AIC-Akaike Bilgi Kriteri, SIC-Schwarz Bilgi Kriteri, HQC-Hannan-Quinn Bilgi Kriteri değerlerini göstermektedir.

Üç farklı dönem için de ARCH-LM test istatistiklerinden hareketle EGARCH, TGARCH ve APGARCH modelleri ile öngörü yapılmıştır. Model seçim kriterlerine göre tüm dönem ve kriz içeren dönem için yine Student-t dağılımlı TGARCH modeli ve kriz sonrası dönem için Student-t dağılımlı EGARCH modelinin en anlamlı modeller oldukları görülmüştür.

Tablo 8'e göre; tüm dönem ve kriz içeren dönem için TGARCH modeli ortalama denkleminde finansal bulaşıcılık katsayısı istatistiki ve iktisadi olarak anlaml bulunmuştur. Buna göre, ERSP500TL'de meydana gelen $\% 1$ oranında değişimin ERBIST30TL'de tüm dönemde \%0,298528 oranında ve kriz içeren dönemde $\% 0,367915$ oranında aynı yönlü bir değişime neden olduğu görülmüştür. Kriz içeren dönemde finansal bulaşıcılık katsayısının yine daha yüksek olduğu anlaşılmıştır. Sürü davranışının varlığını temsil eden YKMSTL katsayısının işareti tüm dönemde ve kriz sonrası dönemde negatif olmakla birlikte sadece kriz içeren dönemde $\% 10$ düzeyinde ve kriz sonrası dönemde istatistiki olarak anlamlıdır. Buna göre, tüm dönemde sürü davranışı yoktur. 2008 küresel finans krizinin kriz içeren dönemde sürü davranışı ile yayıldığı söylenebilir.

Tüm dönem ve kriz içeren dönem için varyans denklemi incelendiğinde; TGARCH modelinde $\alpha$ katsayısı anlamlı çıkmıştır. Getiri serisine gelen şokların hafızada kalma süresini gösteren $\beta$ katsayısı ise 1 yakın olup şokların uzun süre hafızada kaldığını ve gecikmeli olarak ortalamaya döndügünü ifade etmektedir. Asimetri katsayısı $\gamma$, tüm dönem ve kriz içeren dönem için pozitif ve anlamlı bulunmuştur. Bu durumda seriye gelen negatif şokların (olumsuz haberlerin) volatilite üzerinde daha fazla etkiye sahip olduğu anlaşılmıştır. Kriz içeren dönemde asimetri katsayısının beklendiği üzere en yüksek olduğu bulgulanmıştır. Hesaplanan ARCH-LM test istatistiği değerleri, $\chi^{2}$ tablo değerlerinden büyük olduğu için artıklarda (hata terimlerinde) ARCH etkisinin kalmadığ anlaşılmıştır. Ayrıca Ljung-Box istatistikleri itibarıyla standartlaştırılmış (tüm dönem hariç) ve kareli standartlaştırılmış artıklarda seri korelasyon kalmadığı görülmüștür. 
Tablo 8. Asimetrik GARCH Tipi Modellerin Öngörü Sonuçları (TL Bazlı)

\begin{tabular}{|c|c|c|c|c|c|c|c|c|c|}
\hline \multirow[b]{2}{*}{ Katsayı } & \multicolumn{3}{|c|}{ EGARCH(1,1) Modeli } & \multicolumn{3}{|c|}{ TGARCH(1,1) Modeli } & \multicolumn{3}{|c|}{ APGARCH(1,1) Modeli } \\
\hline & TD & KİD & KSD & TD & KİD & KSD & TD & KİD & KSD \\
\hline C & $\begin{array}{c}0,000243 \\
(0,336124) \\
{[0,7368]}\end{array}$ & $\begin{array}{c}-0,001136 \\
(-0,991207) \\
{[0,3216]}\end{array}$ & $\begin{array}{c}0,002119 \\
(2,469357) \\
{[0,0135]}\end{array}$ & $\begin{array}{c}0,000531 \\
(0,725646) \\
{[0,4681]}\end{array}$ & $\begin{array}{c}-0,001281 \\
(-1,093908) \\
{[0,2740]}\end{array}$ & $\begin{array}{c}0,002742 \\
(3,072025) \\
{[0,0021]}\end{array}$ & $\begin{array}{c}0,000449 \\
(0,613186) \\
{[0,5398]}\end{array}$ & $\begin{array}{c}-0,001340 \\
(-1,149432) \\
{[0,2504]}\end{array}$ & $\begin{array}{c}-0,002661 \\
(2,950054) \\
{[0,0032]}\end{array}$ \\
\hline ERSP500TL & $\begin{array}{c}0,298147 \\
(16,78466) \\
{[0,0000]}\end{array}$ & $\begin{array}{c}0,370616 \\
(14,70283) \\
{[0,0000]}\end{array}$ & $\begin{array}{c}0,217177 \\
(8,837995) \\
{[0,0000]}\end{array}$ & $\begin{array}{c}0,298528 \\
(16,76808) \\
{[0,0000]}\end{array}$ & $\begin{array}{c}0,367915 \\
(14,47909) \\
{[0,0000]}\end{array}$ & $\begin{array}{c}0,221513 \\
(9,057458) \\
{[0,0021]}\end{array}$ & $\begin{array}{c}0,298528 \\
(16,76808) \\
{[0,0000]}\end{array}$ & $\begin{array}{c}0,369665 \\
(14,53703) \\
{[0,0000]}\end{array}$ & $\begin{array}{c}0,220806 \\
(9,002880) \\
{[0,0000]}\end{array}$ \\
\hline YKMSTL & $\begin{array}{c}-0,010117 \\
(-0,201456) \\
{[0,8403]}\end{array}$ & $\begin{array}{c}0,131420 \\
(1,735618) \\
{[0,0000]}\end{array}$ & $\begin{array}{c}-0,205013 \\
(-3,352641) \\
{[0,0008]}\end{array}$ & $\begin{array}{c}-0,031958 \\
(-0,632231) \\
{[0,5272]}\end{array}$ & $\begin{array}{c}0,142811 \\
(1,871863) \\
{[0,0621]}\end{array}$ & $\begin{array}{c}-0,252484 \\
(-3,938274) \\
{[0,0001]}\end{array}$ & $\begin{array}{c}-0,025700 \\
(-0,508520) \\
{[0,6111}\end{array}$ & $\begin{array}{c}0,146877 \\
(1,929573) \\
{[0,0537]}\end{array}$ & $\begin{array}{c}-0,250415 \\
(-3,850006) \\
{[0,0001]}\end{array}$ \\
\hline $\mathbf{w}_{\mathbf{0}}$ & $\begin{array}{c}-0,292347 \\
(-5,794646) \\
{[0,0000]}\end{array}$ & $\begin{array}{c}-0,439458 \\
(-4,946196) \\
{[0,0000]}\end{array}$ & $\begin{array}{c}-0,120940 \\
(-4,051960) \\
{[0,0001]}\end{array}$ & $\begin{array}{c}6,28 \mathrm{E}-06 \\
(4,372505) \\
{[0,0000]}\end{array}$ & $\begin{array}{c}1,10 \mathrm{E}-05 \\
(3,651369) \\
{[0,0003]}\end{array}$ & $\begin{array}{c}2,15 \mathrm{E}-07 \\
(3,357912) \\
{[0,0008]}\end{array}$ & $\begin{array}{c}1,08 \mathrm{E}-05 \\
(0,749922) \\
{[0,4533]}\end{array}$ & $\begin{array}{c}6,84 \mathrm{E}-05 \\
(0,089341) \\
{[0,5363]}\end{array}$ & $\begin{array}{c}6,61 \mathrm{E}-05 \\
(0,553604) \\
{[0,5798]}\end{array}$ \\
\hline$\alpha$ & $\begin{array}{c}0,123825 \\
(7,107976) \\
{[0,0000]}\end{array}$ & $\begin{array}{c}0,172845 \\
(5,909880) \\
{[0,0000]}\end{array}$ & $\begin{array}{c}0,023411 \\
(1,664889) \\
{[0,0959]}\end{array}$ & $\begin{array}{c}0,02798 \\
(2,906207) \\
{[0,0000]}\end{array}$ & $\begin{array}{c}0,041327 \\
(2,412836) \\
{[0,0158]}\end{array}$ & $\begin{array}{c}-0,010602 \\
(3,357912) \\
{[0,0008]}\end{array}$ & $\begin{array}{c}0,060067 \\
(4,856347) \\
{[0,0000]}\end{array}$ & $\begin{array}{c}0,089341 \\
(4,570396) \\
{[0,0000]}\end{array}$ & $\begin{array}{c}0,020662 \\
(3,001087) \\
{[0,0027]}\end{array}$ \\
\hline$\beta$ & $\begin{array}{c}0,976394 \\
(184,4150) \\
{[0,0000]}\end{array}$ & $\begin{array}{c}0,962728 \\
(100,2652) \\
{[0,0000]}\end{array}$ & $\begin{array}{c}0,988120 \\
(319,4835) \\
{[0,0000]}\end{array}$ & $\begin{array}{c}0,914653 \\
(77,49582) \\
{[0,0000]}\end{array}$ & $\begin{array}{c}0,875297 \\
(41,21703) \\
{[0,0000]}\end{array}$ & $\begin{array}{c}0,973838 \\
4,428906 \\
{[0,0000]}\end{array}$ & $\begin{array}{c}0,915845 \\
(78,37693) \\
{[0,0000]}\end{array}$ & $\begin{array}{c}0,878030 \\
(42,81466) \\
{[0,0000]}\end{array}$ & $\begin{array}{c}0,969292 \\
(141,1252) \\
{[0,0000]}\end{array}$ \\
\hline$\gamma$ & $\begin{array}{c}-0,056308 \\
(-5,749167) \\
{[0,0000]}\end{array}$ & $\begin{array}{c}-0,072412 \\
(-4,300467) \\
{[0,0000]}\end{array}$ & $\begin{array}{c}-0,053181 \\
(-5,107147) \\
{[0,0000]}\end{array}$ & $\begin{array}{c}0,06534 \\
(4,861356) \\
{[0,0000]}\end{array}$ & $\begin{array}{c}0,091210 \\
(3,809996) \\
{[0,0000]}\end{array}$ & $\begin{array}{c}0,049387 \\
(4,428906) \\
{[0,0000]}\end{array}$ & $\begin{array}{c}0,332452 \\
(3,895832) \\
{[0,0000]}\end{array}$ & $\begin{array}{c}0,350209 \\
3,163434 \\
{[0,0016]}\end{array}$ & $\begin{array}{c}0,999965 \\
4,8 \mathrm{E}+103 \\
{[0,0000]}\end{array}$ \\
\hline$\delta$ & - & - & - & - & - & - & $\begin{array}{c}1,751287 \\
(5,588016) \\
{[0,0000} \\
\end{array}$ & $\begin{array}{c}1,568614 \\
(4,044597) \\
{[0,0001]}\end{array}$ & $\begin{array}{c}1,206123 \\
(2,946926) \\
{[0,0032]}\end{array}$ \\
\hline $\mathbf{L L}$ & $9.324,30$ & $4.671,54$ & $4.683,71$ & $9.327,71$ & $4.672,83$ & $4.681,16$ & $9.328,06$ & $4.673,224$ & $4.682,517$ \\
\hline AIC & $-5,548717$ & $-5,378938$ & $-5,758263$ & $-5,550753$ & $-5,380425$ & $-5,755122$ & $-5,550365$ & $-5,379728$ & $-5,755563$ \\
\hline SIC & $-5,534140$ & $-5,353756$ & $-5,731699$ & $-5,536175$ & $-5,355243$ & $-5,728557$ & $-5,533964$ & $-5,351398$ & $-5,725678$ \\
\hline HQC & $-5,543504$ & $-5,369625$ & $-5,748406$ & $-5,545539$ & $-5,371112$ & $-5,745265$ & $-5,544499$ & $-5,369251$ & $-5,744474$ \\
\hline ARCH-LM & $\begin{array}{c}0,005178 \\
(0,9426)\end{array}$ & $\begin{array}{c}0,028954 \\
(0,8649)\end{array}$ & $\begin{array}{c}0,490389 \\
(0,4838)\end{array}$ & $\begin{array}{c}0,455110 \\
(0,4999)\end{array}$ & $\begin{array}{c}-0,008311 \\
(0,9274)\end{array}$ & $\begin{array}{c}0,320787 \\
(0,5821)\end{array}$ & $\begin{array}{c}0,235657 \\
(0,6274)\end{array}$ & $\begin{array}{c}0,003191 \\
(0,9550)\end{array}$ & $\begin{array}{l}0,602827 \\
(0,4375)\end{array}$ \\
\hline$Q(10)$ & $\begin{array}{l}23,554 \\
(0,009)\end{array}$ & $\begin{array}{l}7,7883 \\
(0,650)\end{array}$ & $\begin{array}{l}18,161 \\
(0,052)\end{array}$ & $\begin{array}{l}23,508 \\
(0,009)\end{array}$ & $\begin{array}{l}8,5531 \\
(0,575)\end{array}$ & $\begin{array}{l}17,911 \\
(0,056)\end{array}$ & $\begin{array}{l}23,527 \\
(0,009)\end{array}$ & $\begin{array}{l}7,8720 \\
(0,641)\end{array}$ & $\begin{array}{c}19,394 \\
(0,0036)\end{array}$ \\
\hline$Q^{2}(10)$ & $\begin{array}{l}12,820 \\
(0,234)\end{array}$ & $\begin{array}{c}6,6941 \\
(0,754)\end{array}$ & $\begin{array}{l}13,583 \\
(0,193)\end{array}$ & $\begin{array}{l}9,1948 \\
(0,519)\end{array}$ & $\begin{array}{l}5,8449 \\
(0,828)\end{array}$ & $\begin{array}{c}8,7106 \\
(0,560)\end{array}$ & $\begin{array}{r}9,1948 \\
(0,519)\end{array}$ & $\begin{array}{c}6,5694 \\
(0,765)\end{array}$ & $\begin{array}{l}11,000 \\
(0,350)\end{array}$ \\
\hline
\end{tabular}

Not: TD: Tüm Dönem, KID: Kriz İçeren Dönem, KSD: Kriz Sonrası Dönem. z-istatistikleri parantez içinde, olasılık (probability) değerleri köșeli parantez içinde gösterilmiştir. LL-Log-Olasllık, AIC-Akaike Bilgi Kriteri, SIC-Schwarz Bilgi Kriteri, HQC-Hannan-Quinn Bilgi Kriteri değerlerini göstermektedir. ARCH-LM 1 gecikmeli ARCH test istatistiğini, Q(10) ve Q2(10) sırasıyla standardize edilmiş ve karesi alınmıș hataların test istatistiklerini (Ljung-Box) göstermektedir. Parantez içindeki değerler gecikmelerini vermektedir.

Yine Tablo 8'de kriz sonrası dönem dikkate alındığında daha anlamlı bulunan EGARCH modeli itibarıly ortalama denkleminde finansal bulaşıcılık katsayısı istatistiki ve iktisadi olarak anlamlı bulunmuştur. Buna göre ERSP500TL'de meydana gelen \%1 oranında değişimin ERBIST30TL'de $\% 0,217177$ oranında aynı yönlü bir değişime neden olduğu görülmüștür. Bunun yanında, krizin sürü davranışı ile yayılma etkisini gösteren YKMSTL katsayısının işareti beklendiği gibi negatif olup istatistiki ve iktisadi olarak anlamlı bulunmuştur. Buna göre, YKMSTL'de meydana gelen $\% 1$ oranında azalma ERBIST30TL'de krizin sürü davranışı ile yayılmasını $\% 0,205013$ oranında artırmaktadır. Varyans denklemine göre, kriz sonrası dönem için EGARCH modelinde $\alpha$ katsayısı \%10 düzeyinde istatistiki olarak anlamlı çıkmıştır. Getiri serisine gelen şokların hafızada kalma süresini gösteren $\beta$ katsayısı TGARCH modeline göre daha fazla 1 yakın olup şokların uzun süre hafızada kaldığını ifade etmektedir. Nitekim $\beta$ katsayısı tüm dönem ve kriz içeren döneme göre daha da yüksek bulunmuştur. Asimetri katsayısı $\gamma$, kriz sonrası dönem için negatif (TGARCH modelinde de pozitif) ve anlamlı bulunmuştur. Bu durumda seriye gelen negatif şokların (olumsuz haberlerin) BİST30 endeks oynaklığını daha fazla artırdığı anlașılmıștır. Kriz sonrası dönemde asimetri katsayısının beklendiği 
üzere kriz içeren döneme göre düştüğü gözlenmiştir. ARCH-LM test istatistiği itibarıyla artıklarda (hata terimlerinde) ARCH etkisinin kalmadığı anlaşılmıştır. Ayrıca LjungBox istatistikleri itibarıyla standartlaştırılmış ve kareli standartlaştırılmış artıklarda seri korelasyon kalmadığı görülmüștür

Analize konu tüm değişkenlerin yerel para birimleri cinsinden, USD cinsinden ve TL cinsinden gerçekleştirilen model sonuçlarına göre, finansal bulaşıcılık katsayısı, krizin yayılma etkisini gösteren sürü davranışı katsayısı, ARCH ve GARCH katsayıları ile şokların/haberlerin etkilerini gösteren asimetri katsayısı $\gamma$, özellikle kriz sonrası dönem için istatistiki ve iktisadi olarak anlamlı çıkmıştır.

Yerel para birimleri ile USD veya TL cinsinden yapılan analizlerde elde edilen katsayıların işaretleri hem EKKY hem de asimetrik GARCH tipi modeller bağlamında dönem bazında da karşılaștırılmıştır. Burada amaç, her analiz dönemi için para cinsi farklılaştığında özellikle ortalama denklemlerinde yer alan finansal bulaşıcılık katsayısı (ERSP500) ve krizin yayılma etkisini gösteren sürü davranışı katsayısı (YKMS) işaretlerinin değişip değişmediğini ortaya koymaktır.

Bununla birlikte, Tablo 1'deki tanımlayıcı istatistiklere göre seriler normal dağılmadığından, EKKY modelinin yanlı sonuç verme eğilimi nedeniyle, EKKY yerine asimetrik GARCH tipi modellerin yorumlanmasının daha uygun olacağına karar verilmiştir. Buradan hareketle, farklı para birimleri cinsinden tüm dönem, kriz içeren dönem ve kriz sonrası dönem için asimetrik GARCH tipi modellerin öngörü sonuçları Tablo 9'da bir arada sunulmuştur.

Tablo 9'a göre, tüm dönem dikkate alındığında TGARCH modeline göre, para birimleri değişse de finansal bulaşıcılık söz konusu iken krizin sürü davranışı ile yayılma etkisi istatistiki ve/veya iktisadi olarak anlamsız bulunmuştur. Kriz içeren dönem dikkate alındığında TGARCH modeline göre, para birimleri değişse de yine finansal bulaşıcılık söz konusu iken krizin sürü davranışı ile yayılma etkisi yerel para birimi bazlı olduğunda \%5 düzeyinde, USD ve TL bazlı olduğunda ise \%10 düzeyinde istatistiki olarak anlamlı olmasına karşın işaretin yönü beklendiği gibi negatif olmadığından iktisadi olarak anlamsız bulunmuştur. Nitekim, kriz sonrası dönem dikkate alındığında en anlamlı bulunan EGARCH modeline göre, para birimleri değişse de hem finansal bulașıcllık hem de krizin sürü davranışı ile yayılma etkisi istatistiki ve iktisadi olarak anlamlı bulunmuştur.

Bu noktada çalışmanın önemli bir bulgusu, her analiz dönemi için para cinsi farklılaştığında özellikle ortalama denklemlerinde yer alan finansal bulaşıcılık katsayısı (ERSP500) ve krizin yayılma etkisini gösteren sürü davranışı katsayısı (YKMS) işaretlerinin değişmediği yönündedir. Yapılan analiz itibarıyla değişkenler için para cinsi uyumlaştırmasına gerek olmadı̆̆ı söylenebilir. Para cinsi farklılaştığında elbette katsayı büyüklükleri değișmekte ancak ilişkinin varlığ ve yönü kesinlikle değişmemektedir. Tablo 9'dan görüleceği üzere finansal bulaşıcılık katsayıları (ERSP500), yerel para birimleri bazlı ve USD bazlı yapılan analizlerde neredeyse birbiriyle aynı olmasına karşın, TL bazlı yapılan analizlerde ciddi anlamda düşüş göstermiştir. $\mathrm{Bu}$ durumda TL bazlı analiz yapıldığında ilişkinin yönü değişmese de şiddetinin azaldığı söylenebilir. Sonuç olarak, üç farklı dönem için de finansal bulaşıcılık etkisi söz konusu iken krizin sürü davranışı ile yayılma etkisinin sadece kriz sonrası dönemde olduğu bulgulanmiştır.

Model seçim kriterlerine göre tüm dönem ve kriz içeren dönem için TGARCH modeli buna karşın, kriz sonrası dönem için EGARCH modeli en anlamlı bulunmuştu. Buradan hareketle üç dönemin volatilite katsaylları ile half-life şok değerlerini gün sayısı itibarıyla karşılaştırmak önem arz etmektedir.

Üç farklı dönem için sabit varyans ve ilgili asimetrik GARCH tipi modellerden elde edilen değișen varyansa dayalı volatilite katsayıları ile yaşanan şoklardan sonra getiri serisinin kaç gün içinde ortalamaya döndüğünü (şokların 
söndüğünü) gösteren half-life şok değerleri

Tablo 10'da sunulmuştur.

Tablo 9: Farklı Para Birimleri Cinsinden Ortalama Denklemlerinin Öngörü Sonuçlarının Karşılaştırılması

\begin{tabular}{|c|c|c|c|c|c|c|c|c|c|}
\hline \multirow[b]{3}{*}{ Katsayı } & \multicolumn{3}{|c|}{ Tüm Dönem } & \multicolumn{3}{|c|}{ Kriz İçeren Dönem } & \multicolumn{3}{|c|}{ Kriz Sonrası Dönem } \\
\hline & \multicolumn{3}{|c|}{ TGARCH $(1,1)$ Student-t } & \multicolumn{3}{|c|}{ TGARCH $(1,1)$ Student-t } & \multicolumn{3}{|c|}{ EGARCH $(1,1)$ Student-t } \\
\hline & $\begin{array}{c}\text { Yerel Para } \\
\text { Bazlı }\end{array}$ & $\begin{array}{c}\text { USD } \\
\text { Bazlı }\end{array}$ & $\begin{array}{c}\text { TL } \\
\text { Bazlı }\end{array}$ & $\begin{array}{c}\text { Yerel Para } \\
\text { Bazlı }\end{array}$ & $\begin{array}{l}\text { USD } \\
\text { Bazlı }\end{array}$ & $\begin{array}{c}\text { TL } \\
\text { Bazlı }\end{array}$ & $\begin{array}{c}\text { Yerel Para } \\
\text { Bazlı }\end{array}$ & $\begin{array}{l}\text { USD } \\
\text { Bazlı }\end{array}$ & $\begin{array}{c}\text { TL } \\
\text { Bazlı }\end{array}$ \\
\hline C & $\begin{array}{c}6,44 \mathrm{E}-05 \\
(0,090209) \\
{[0,9281]}\end{array}$ & $\begin{array}{c}0,000369 \\
(0,452508) \\
{[0,6509]}\end{array}$ & $\begin{array}{c}0,000531 \\
(0,725646) \\
{[0,4681]}\end{array}$ & $\begin{array}{c}-0,001595 \\
(- \\
1,397662) \\
{[0,1622]}\end{array}$ & $\begin{array}{c}-0,001113 \\
(-0,884627) \\
{[0,3764]}\end{array}$ & $\begin{array}{c}-0,001281 \\
(-1,093908) \\
{[0,2740]}\end{array}$ & $\begin{array}{c}0,001300 \\
(1,547749) \\
{[0,1217]}\end{array}$ & $\begin{array}{c}0,002836 \\
(2,629454) \\
{[0,0086]}\end{array}$ & $\begin{array}{c}0,002119 \\
(2,469357) \\
{[0,0135]}\end{array}$ \\
\hline ERSP500 & $\begin{array}{c}0,477873 \\
(21,89064) \\
{[0,0000]}\end{array}$ & $\begin{array}{c}0,478130 \\
(19,39651) \\
{[0,0000]}\end{array}$ & $\begin{array}{c}0,298528 \\
(16,76808) \\
{[0,0000]}\end{array}$ & $\begin{array}{c}0,505177 \\
(17,64879) \\
{[0,0000]}\end{array}$ & $\begin{array}{c}0,497739 \\
(15,79817) \\
{[0,0000]}\end{array}$ & $\begin{array}{c}0,367915 \\
(14,47909) \\
{[0,0000]}\end{array}$ & $\begin{array}{c}0,425604 \\
(11,63315) \\
{[0,0000]}\end{array}$ & $\begin{array}{c}0,426815 \\
(10,03032) \\
{[0,0000]}\end{array}$ & $\begin{array}{c}0,217177 \\
(8,837995) \\
{[0,0000]}\end{array}$ \\
\hline YKMS & $\begin{array}{c}0,003099 \\
(0,062949) \\
{[0,9498]}\end{array}$ & $\begin{array}{c}-0,023114 \\
(-0,406795) \\
{[0,6842]}\end{array}$ & $\begin{array}{c}-0,031958 \\
(-0,632231) \\
{[0,5272]}\end{array}$ & $\begin{array}{c}0,152262 \\
(2,055935) \\
(0,0398)\end{array}$ & $\begin{array}{c}0,137146 \\
(1,657797) \\
{[0,0974]}\end{array}$ & $\begin{array}{c}0,142811 \\
(1,871863) \\
{[0,0621]}\end{array}$ & $\begin{array}{c}-0,131680 \\
(-2,19230) \\
{[0,0284]}\end{array}$ & $\begin{array}{c}-0,296235 \\
(-3,707089) \\
{[0,0002]}\end{array}$ & $\begin{array}{c}-0,205013 \\
(-3,352641) \\
{[0,0008]}\end{array}$ \\
\hline $\mathbf{L L}$ & $9.396,27$ & $8.980,04$ & $9.327,71$ & $4.707,54$ & $4.539,17$ & $4.672,83$ & $4.710,73$ & $4.457,22$ & $4.683,71$ \\
\hline AIC & $-5,591583$ & $-5,343682$ & $-5,550753$ & $-5,420461$ & $-5,226265$ & $-5,380425$ & $-5,791533$ & $-5,479344$ & $-5,758263$ \\
\hline SIC & $-5,577005$ & $-5,321904$ & $-5,536175$ & $-5,395279$ & $-5,201084$ & $-5,355243$ & $-5,764968$ & $-5,452779$ & $-5,731699$ \\
\hline HQC & $-5,586370$ & $-5,338468$ & $-5,545539$ & $-5,411148$ & $-5,216952$ & $-5,371112$ & $-5,781676$ & $-5,469487$ & $-5,748406$ \\
\hline
\end{tabular}

Tablo 10: ERBIST30 Volatilite ve Half-life Şok Değerleri

\begin{tabular}{|c|c|c|c|c|c|c|}
\hline & \multicolumn{3}{|c|}{ ERBİST30TL } & \multicolumn{3}{|c|}{ ERBISTT30USD } \\
\hline & $\begin{array}{c}\text { (Tüm } \\
\text { Dönem) }\end{array}$ & $\begin{array}{c}\text { (Kriz } \\
\text { İçeren } \\
\text { Dönem) }\end{array}$ & $\begin{array}{c}\text { (Kriz } \\
\text { Sonrası } \\
\text { Dönem) }\end{array}$ & $\begin{array}{c}\text { (Tüm } \\
\text { Dönem) }\end{array}$ & $\begin{array}{c}\text { (Kriz } \\
\text { İçeren } \\
\text { Dönem) }\end{array}$ & $\begin{array}{c}\text { (Kriz } \\
\text { Sonrası } \\
\text { Dönem) }\end{array}$ \\
\hline Asimetrik GARCH Tipi Volatilite Katsayısı (HeV) & 0,015946 & 0,017065 & 0,013516 & 0,017424 & 0,018379 & 0,015420 \\
\hline Sabit Volatilite Katsayısı (HoV) & 0,017234 & 0,019204 & 0,014848 & 0,019756 & 0,021707 & 0,017423 \\
\hline Oynaklık Karşılaştırması & $\mathrm{HeV}<\mathrm{HoV}$ & $\mathrm{HeV}<\mathrm{HoV}$ & $\mathrm{HeV}<\mathrm{HoV}$ & $\mathrm{HeV}<\mathrm{HoV}$ & $\mathrm{HeV}<\mathrm{HoV}$ & $\mathrm{HeV}<\mathrm{HoV}$ \\
\hline Half-life (HL) Şok Değeri (Gün) & 28 & 18 & 58 & 13 & 17 & 68 \\
\hline
\end{tabular}

Not: HoV (Homoscedastic Volatility) sabit varyansa dayalı standart sapmayı, HeV (Heteroskedastic Volatility) değişen varyansa dayalı standart sapmayı ifade etmektedir.

Tablo 10'a göre, üç farklı dönem için de ERBIST30USD endeks volatilitesi ERBIST30TL endeks volatilitesinden yüksektir. Her iki para birimi cinsinden de ERBİST30 için hesaplanan $\mathrm{HoV}$ (Homoscedastic Volatility) ve $\mathrm{HeV}$ (Heteroskedastic Volatility) katsayıları en yüksek değerlerine kriz içeren dönemde ulaşmışlardır. Kriz sonrası dönemde hem HoV hem HeV katsayıları düşmüştür. Her üç dönemde de HoV katsayısı HeV katsayısından daha yüksektir. Buna göre, koşullu değișen varyansa dayalı TGARCH(1,1) ve EGARCH $(1,1)$ modellerinde riskin daha düşük olduğu görülmüştür. Şoklardan sonra ERBIST30TL endeksi getiri serisinin tüm dönemde 28 gün, kriz içeren dönemde 18 gün ve kriz sonrası dönemde 58 gün içinde ortalamaya döndüğü (şokların söndüğü) anlaşılmıştır. Buna karşın, ERBIST30USD endeksi getiri serisinin tüm dönemde 13 gün, kriz içeren dönemde 17 gün ve kriz sonrası dönemde 68 gün içinde ortalamaya döndüğü (şokların söndüğü) görülmüștür. Burada ilginç olan, her iki para cinsinden de ortalamaya dönüşün kriz içeren dönemde birbirine yakın ve kısa olmasıdır. Bunun yanında, USD cinsine dönüştürüldüğünde tüm dönem için ortalamaya dönüş süresi kısalmasına karşın, kriz sonrası dönem için uzamıştır.

\section{SONUÇ}

Çalışmada 5 Ocak 2006 - 12 Kasım 2019 dönemi günlük kapanış fiyatları üzerinden ayrıca iki alt dönem belirlenerek, yatay kesit 
mutlak sapmaya dayalı olarak S\&P500 endeksi ile BİST30 endeksi arasında finansal bulaşıcılık etkisi ve sürü davranışının varlığı incelenmiştir. Geliștirilen "Finansal Bulașıcılık Modeli" hem EKKY hem de asimetrik GARCH tipi modeller kullanılarak öngörümlenmiştir. Bilgi kriterleri dikkate alındığında tüm dönem ve kriz içeren dönemde TGARCH modeli kriz sonrası dönemde ise EGARCH modeli en iyi öngörü sonuçlarını vermiştir.

Analize konu tüm değişkenlerin yerel para birimleri cinsinden, USD cinsinden ve TL cinsinden gerçekleștirilen model sonuçlarına göre, tüm dönem dikkate alındığında TGARCH modeline göre, para birimleri değişse de finansal bulaşıcıllk söz konusu iken krizin sürü davranışı ile yayılma etkisi istatistiki ve/veya iktisadi olarak anlamsız bulunmuştur. Kriz içeren dönem dikkate alındığında TGARCH modeline göre, para birimleri değişse de yine finansal bulaşıcılık söz konusu iken krizin sürü davranışı ile yayılma etkisi yerel para birimi bazlı olduğunda \%5 düzeyinde, USD ve TL bazlı olduğunda ise \%10 düzeyinde istatistiki olarak anlamlı olmasına karşın işaretin yönü beklendiği gibi negatif olmadığından iktisadi olarak anlamsız bulunmuștur. Nitekim, kriz sonrası dönem dikkate alındığında en anlamlı bulunan EGARCH modeline göre, para birimleri değişse de hem finansal bulaşıcılık hem de krizin sürü davranışı ile yayılma etkisi istatistiki ve iktisadi olarak anlamlı bulunmuștur.

Bu noktada çalışmanın önemli bir bulgusu, her analiz dönemi için para cinsi farklılaştığında özellikle ortalama denklemlerinde yer alan finansal bulaşıcılık katsayısı (ERSP500) ve krizin yayılma etkisini gösteren sürü davranışı katsayısı (YKMS) işaretlerinin değișmediğgi yönündedir. Yapılan analiz itibarıyla değişkenler için para cinsi uyumlaştırmasına gerek olmadığı söylenebilir. Para cinsi farklılaştığında elbette katsayı büyüklükleri değişmekte ancak ilişskinin varlığı ve yönü kesinlikle değişmemektedir. Üç farklı dönem için de finansal bulaşıcılık etkisi söz konusu iken krizin sürü davranışı ile yayılma etkisinin beklentinin aksine sadece kriz sonrası dönemde olduğu bulgulanmıştır. Bu sonuç sürü davranışının kriz sonrasında görüldügünü göstermekte ve ülkedeki yatırımcı davranışlarının bir örüntüsünü ortaya koymaktadır. Nitekim Türkiye'deki yatırımcıların kriz beklentisinden daha çok korktukları söylenebilir. Kriz dönemlerinde yatırımcıların birbirine olan güveni azalıp sadece kendi bilgilerine/sezgilerine inanarak pozisyon alabileceği için sürü davranışının oluşması için gerekli ortam kaybolabilir.

Sürü davranışını görülmediği piyasalar finansal varlıkları fiyatlama modelinin varsayımlarını doğrulamaktadır. Algı ile olgu arasındaki farkın ne kadar önemli olduğu bir kez daha anlaşılmıștır. İnsan doğası gereği kaotik bir yapıya sahiptir. Bu nedenle insan davranışını çözümlemeye çalışırken kontrol edilemeyen birçok değişken ile çalışılmaktadır. $\mathrm{Bu}$ durum piyasalarda yaşanan anomalilerin ne kadar önemli olduğunu da göstermektedir. Bilgi asimetrisinin oluşturduğu sapmaların nedeni yatırımcı davranışlarının analiz edilmesi ile daha anlaşılır hale gelebilir. Bu nedenle bundan sonra yapılacak çalışmalarda yatırımcı davranışlarının hangi habere nasıl bir tepki verdiği analiz edilerek fiyatların oluşumu hakkında daha fazla bilgi sahibi olunabilir. Ayrıca Covid-19 pandemi sürecinin borsa endekslerinde meydana getirdiği kriz etkilerinin yine finansal bulaşıcllık ve sürü davranışı yönünden analiz edilmesinin literatür açısından faydalı olacağı düşünülmektedir.

\section{REFERANSLAR}

ALEXANDER, C. (2001). Market Models: A Guide to Financial Data Analysis, Wiley.

BEKAERT, G. EHRMANN, M., MEHL, A. (2011). Global Crises and Equity Market Contagion,
European Central Bank Working Paper Series, No:1381, 1-45. 


\section{D. ÖZDEN - M. URAL}

BERNANKE, B.S. (2013). Board of Governers of the Reserve System before the Joint Economic Comittie U.S. Congress, May 22 2013, 1-8

BOLGÜN, K.E. VE AKÇAY, B.M. (2005). Risk Yönetimi. 2.Baskı, İstanbul: Scala Yayıncılık.

BOLLERSLEV, T. (1986). Generalized Autoregressive Conditional Heteroskedasticity. Journal of Econometrics, 31(3):307-327.

CARAMAZZO, F. RICCI, L., SALGADO, R. (2000). Trade and Financial Contagion in Currency Crises, IMF Working Paper, 1-48.

CHANG, E. C., CHENG J.W., KHORANA, A., (2000). An Examination of Herd Behavior in Equity Markets: An International Perspective. Journal of Banking \& Finance. 24(10):1651-1679.

CHRISTIE, W.G., HUANG, R.D. (1995). Following the Pied Piper: Do Individual Returns Herd around the Market", Financial Analysts Journal, 51, 31-37.

DING, Z., GRANGER, C.W.J., Engle. R.F. (1993) A Long Memory Property of Stock Market Returns and A New Model. Journal of Empirical Finance, (1):83-106.

DOĞUKANLI, H., ERGÜN, B. (2015). BİST’te Sürü Davranışı: Hwang ve Salmon Yöntemi ile Bir Araştırma. Finans Politik \& Ekonomik Yorumlar Dergisi, 52(603):1-18.

DUNGEY, M., TAMBAKIS, D. (2003). International Financial Contagion: What Do We Know? Cambridge Working Papers in Economics (CWPE), 9:1-23.

ELKHALDI, A., ABELFATTEH, Y. B. (2014). Testing Herding Effects on Financial Assets Pricing: The Case of the Tunisian Stockl Market. British Journal of Economics Management\&Trade, 4(7):10461059.

ENGLE, R.F. (1982). Autoregressive Conditional Heteroscedasticity with Estimates of the Variance of United Kingdom Inflation. Econometrica, 50(4):987-1007.

ENGLE, R.F., PATTON, A.J. (2001). What Good Is a Volatility Model?. Quantitative Finance, 1(2):237245.

FAMA, E.F. (1998). Market Efficiency, Long-term Returns, and Behavioral Finance. Journal of Financial Economics, 49(3):283-306.

GBENRO, N., MOUSSA, R.K. (2019). Asymmetric Mean Reversion in Low Liquid Markets: Evidence from BRVM. Journal of Risk and Financial Management. 12(38): 1-19.

HWANG, I., IN, F.H., KIM, T.S. (2010). Contagion Effects of the U.S Subprime Crisis on International Stock Markets, Social Science Research Network, 149.

INDARS, E.R. VE SAVIN, A. (2017). Herding Behavior in an Emerging Market: Evidence From Moscow Exchange. Stockholm School of Economics (SSE) Riga Student Papers, 10(197):1-45.

KAHNEMAN, D. (2015). Hızlı ve Yavaş Düşünme. 11.Basım, İstanbul: Varlık Yayınları.

KAHNEMAN, D., TVERSKY, A. (1979). An Analysis of Decision Under Risk. Econometrica, 47(2):263291.

KAHNEMAN, D., TVERSKY, A. (1979). Prospect Theory: An Analysis of Decision Under Risk. Econometrica, 47(2):263-291.

KAMINSKY, G.L., REINHART, C.M., VEGH, C.A. (2003). The Unholy Trinity of Financial Contagion. NBER Working Papers, No:10061:1-40.

KASA, K. (1992). Common stochastic trends in international stock markets. Journal of Monetary Economics, 29(1):95-124.

KIRAÇ, F., ÇİÇEK, M. (2017). Mortgage Krizinin Uluslararası Hisse Senetleri Piyasası Üzerine Bulaşma Etkisi. Yakın Doğu Üniversitesi Sosyal Bilimler Dergisi, 10(1):75-97.

Kocabıyık, T., Kalaycı, Ş. (2014) Borsalar Arasında Etkileşim: G-8 Ülkeleri ve Türkiye Üzerine Ampirik Bir Araştırma. Finans Politik \& Ekonomik Yorumlar Dergisi, 51(594):37-56.

NELSON, D.B. (1991). Conditional Heteroscedasticity in Asset Returns: A New Approach. Econometrica, 59(2):347-370.

SHEFRIN, H., STATMAN, M. (2003). The Contributions of Daniel Kahneman and Amos Tversky. Journal of Behavioral Finance, 4(2):54-58.

TAN, T.A.G. (2012). Stock Market Integration: Case of the Philippines. Philippine Management Review, 19:75-90.

TSAY, R.S. (2005) Analysis of Financial Time Series. 2nd Edition, USA: John Wiley \& Sons, Inc..

URAL, M. (2010). Yatırım Fonlarınin Performans ve Risk Analizi. Ankara: Detay Yayıncılık. 
İzmir İktisat Dergisi (İzmir Journal of Economics), Yll:2020, Cilt:35, Sayl:4, ss. 857-877

ZAKOIAN, J.M. (1994). Threshold Heteroskedastic Models. Journal of Economic Dynamics and Control, 18:931-955.

ZIVOT, E., WANG, J. (2006). Modelling Financial

Time Series with S-PLUS, 2nd Edition, Springer. 